This item was submitted to Loughborough's Research Repository by the author.

Items in Figshare are protected by copyright, with all rights reserved, unless otherwise indicated.

\title{
Beyond protest and discontent. A cross-national analysis of the effect of populist attitudes and issue positions on populist party support
}

PLEASE CITE THE PUBLISHED VERSION

https://doi.org/10.1111/1475-6765.12216

\section{PUBLISHER}

(c) European Journal of Political Research. Published by Wiley.

\section{VERSION}

AM (Accepted Manuscript)

\section{PUBLISHER STATEMENT}

This work is made available according to the conditions of the Creative Commons Attribution-NonCommercialNoDerivatives 4.0 International (CC BY-NC-ND 4.0) licence. Full details of this licence are available at: https://creativecommons.org/licenses/by-nc-nd/4.0/

\section{LICENCE}

CC BY-NC-ND 4.0

\section{REPOSITORY RECORD}

Van Hauwaert, Steven M., and Stijn van Kessel. 2017. "Beyond Protest and Discontent. A Cross-national Analysis of the Effect of Populist Attitudes and Issue Positions on Populist Party Support". Loughborough University. https://hdl.handle.net/2134/24814. 


\title{
Beyond protest and discontent. A cross-national analysis of the effect of populist attitudes and issue positions on populist party support ${ }^{1}$
}

\author{
Steven M. Van Hauwaert (Centro de Investigación y Docencia Económicas, Mexico) \\ Stijn van Kessel (Loughborough University, United Kingdom)
}

Paper accepted by European Journal of Political Research on 5 April 2017

Version: authors' final peer reviewed manuscript, submitted on 11 April 2017

\begin{abstract}
Even though studies of supply-side populism are numerous, its connection with demand-side dynamics, and particularly the populist characteristics or tendencies of the electorate, requires more scholarly attention. We seek to examine in more detail the conditions underlying the support for populist parties, and in particular the role of populist attitudes amongst citizens. We ask two core questions: (i) to what extent are populist party supporters characterised by populist attitudes, and (ii) to what extent do populist (and other) attitudes contribute to their party preference? For the analysis, we use fixed-effect models and rely on a cross-sectional research design that uses unique survey data from 2015 and includes nine European countries. Our results are threefold. First, in line with single-country studies, we conclude that populist attitudes are prominent amongst supporters of left- and right-wing populist parties in particular. Second, populist attitudes are important predictors of populist party support, in addition to left-wing socio-economic issue positions for left-wing populist parties, and authoritarian and anti-immigration issue positions for right-wing populist parties. Third, we find that populist attitudes moderate the effect of issue positions on the support for populist parties, particularly for individuals whose positions are further removed from the extreme ends of the economic or cultural policy scale. These findings suggest that strong populist attitudes may encourage some voters to support a populist party whose issue positions are incongruous with their own policy-related preferences.
\end{abstract}

Keywords: populism, issue positions, populist attitudes, populist party support, crossnational survey data

\footnotetext{
1 The authors would like to thank Rosario Aguilar, Caterina Froio, Robert Huber, Joost van Spanje, Federico Vegetti and, in particular, Christian Schimpf for their comments. We are grateful to the journal editors and the anonymous referees for their extensive feedback and detailed suggestions throughout the review process. All these people contributed to improving the quality of this article, and to the extent that this did not happen, this is certainly our own fault. We presented previous versions of this article at the 2016 ECPR General Conference in Prague, the 2016 Foundation for Migration, Population and Environment (PME BMU) and NCCR 'Populism and Democracy' conference in Zurich, and the 2016 ECPR Joint Sessions in Pisa.
} 


\section{INTRODUCTION}

The rise of populist parties in Europe has attracted considerable scholarly and journalistic attention. Parties associated with the term are typically characterised by an anti-establishment character and an appeal to popular sovereignty. At least in the West European context, they are usually located at the fringes of the ideological spectrum. Academic research sheds light on the character, as well as the electoral success and failure of populist parties - with most studies focusing on parties of the populist radical right, which in Europe is the dominant party family with populism as a defining characteristic (Mudde 2007; Pirro 2014). Many of these studies showed that a vote for populist parties is based on dissatisfaction with the political establishment, but also on ideological convictions and issue positions (see e.g. van der Brug et al. 2000; Schumacher and Rooduijn 2013).

Various studies have thus considered how populist parties meet certain (electoral) demands of voters. What remains understudied, however, is the relationship between populist party support and populist attitudes (but see Stanley 2011; Akkerman et al. 2014). Supporters of populist parties are typically dissatisfied with the political establishment, but do they also sign up to the broader principles of populism, such as its appeal to unmediated popular sovereignty? Furthermore, apart from the case of Slovakia (Stanley 2011) it has not been systematically assessed to what extent populist attitudes contribute to the (electoral) support for populist parties. In other words, do such attitudes matter in terms of party support, or is support for populist parties primarily driven by concrete issue positions or other factors? Using a cross-sectional design, our study asks whether populist party supporters are characterised by populist attitudes, and to what extent these attitudes contribute to their party preference, in addition to other (more policy-related) motivations.

To answer these questions, we use survey data from nine European countries provided by the LIVEWHAT project. It is the first dataset that allows for the cross-national analysis of populist attitudes. Simultaneously, the dataset enables us to relate populist attitudes and policy-related preferences to party support. We provide extensive descriptive evidence and support our claims by designing a set of fixed effects models to help predict populist party support. This latter approach allows us to account for the 
country-specific factors that may prompt populist attitudes and shape party preferences. Altogether, we come to three key findings. First, in line with single-country studies, we conclude that populist attitudes are prominent amongst supporters of left- and rightwing populist parties in particular. Second, populist attitudes are important predictors of populist party support, in addition to left-wing economic issue positions for left-wing populist parties, and authoritarian and anti-immigration issue positions for right-wing populist parties. Third, we find that populist attitudes moderate the effect of issue positions on the support for both left- and right-wing populist parties, particularly for individuals whose positions are further removed from the extreme ends of the economic or cultural policy scale. These findings suggest that strong populist attitudes may encourage some voters to support a populist party whose issue positions are incongruous with their own policy-related preferences.

\section{POPULISM: MATCHING VOTERS WITH PARTIES}

It is often noted that populism is a contested concept that is ill-defined, yet widely applied to a diverse range of movements, parties and actors throughout time and space (e.g. Ionescu and Gellner 1969; Canovan 1981; Taggart 2000). Scholars debate whether we should understand populism as an ideology or set of ideas (e.g. Mudde 2004; Albertazzi and McDonnell 2008; Hawkins 2009), a form of political mobilisation or organisation (e.g. Weyland 2001; Roberts 2006), or rather as a political style (e.g. Jagers and Walgrave 2007; Moffitt and Tormey 2013). It is still true that a broad consensus on the meaning, contents or implications of populism is lacking, and an imprecise and inconsistent use of the term in the vernacular sphere further feeds into conceptual (and operational) confusion (cf. Bale et al. 2012; Aslanidis 2016).

Many present-day scholars, however, take an ideational approach to the concept and broadly agree on populism's attributes (Hawkins 2009; Mudde and Rovira Kaltwasser 2013; Rovira Kaltwasser 2014a). Accordingly, populism makes a Manichean distinction between the corrupt 'elites' and the virtuous 'people', and supports the idea of popular sovereignty. Following Mudde and Rovira Kaltwasser (2012: 8), we can argue that populism might have an 'elective affinity with certain organisational aspects' such as charismatic leadership and unmediated representation, but that these are not defining properties of populism as such. The same can be argued for certain stylistic elements, 
such as confrontational and simplistic language and the proposing of 'sound-bite solutions' (cf. Moffitt and Tormey 2013). These characteristics do not constitute elements of populism per se, but can instead be linked back to the ideational properties of populism, in particular populism's antagonistic position vis-à-vis elites and its appeal to the 'common' people.

An ideational approach to populism allows for the empirical measurement of populist positions of both individuals (demand side) and parties (supply side). Thus far, the focus in the literature has predominantly been on the latter, with scholars measuring degrees of populism by means of party documents and politicians' speeches (Hawkins, 2009; Jagers and Walgrave, 2007; Pauwels, 2011; Rooduijn et al., 2014). This 'degreeist' approach implies that populism can in principle be found in the language of all political actors (to a certain extent) and that populism is not an exclusive feature of a set of 'populist parties' (Rooduijn et al. 2014).

Populism may indeed be a more general feature of certain political systems, particularly in those contexts where trust in political elites is low, such as in European postcommunist countries (see Učeň 2007; Stanley 2011), where confidence in traditional parties received a blow, like in the UK after the so-called expenses scandal (Ford et al. 2012), or where there is a general antipathy towards centralised and big government, such as in the United States (see Kazin 1998; Ware 2002). Concerning the West European context, furthermore, Mudde (2004) has asserted that the emergence of radical right populist parties has induced mainstream parties to use populist rhetoric themselves. According to the same author, this contributes to a "populist Zeitgeist"; yet, this theory remains empirically contested (cf. Rooduijn et al. 2014).

It is questionable, however, whether a 'degreeist' approach to the concept is always theoretically and analytically fruitful (cf. Sartori 1991; van Kessel 2014). Using the concept of democracy as an example, countries may vary in terms of the degree to which they comply with democratic ideals, but there is still value in building a typology of democratic and essentially non-democratic regimes types. The same holds true for populism, which has analytical value as 'a concept of classification'. For some parties, populism is an essential element of their ideology rather than a sporadic (strategic) device used to put distance between themselves and the parties they compete with. Rooduijn et 
al. (2014) showed that certain West European parties clearly stood out in terms of their expression of populist messages, while mainstream parties did not become more populist over time. Populism, in other words, has discriminating power: at least in the West European context, a meaningful distinction can often be made between populist and essentially non-populist parties. In our study, we take this approach and treat populist parties as a bounded category.

While the academic debate concerning populism as part of the political supply side is well developed, the same cannot be said about populism as an individual-level characteristic. The body of research concerning populist expressions amongst citizens and voters is still relatively young and much less extensive. This may be seen as surprising, since, in addition to an element of politicians' discourse or party ideology, populism can be thought of as an individual-level construct, most notably in the form of an attitude (Stanley 2011; Van Hauwaert et al. 2017). We deem this relevant, as populism as a latent attitudinal construct can conceivably play an important role in motivating party support and voting behaviour. Hence, the notion that populism also exists as part of the political demand side gives rise to some unanswered questions, most notably related to the impact and explanatory value of 'populist attitudes'.

To draw attention to the general composition of populist attitudes, recent scholarship developed several measurements that are gradually becoming standard items in the effort to gauge populist attitudes (cf. Hawkins and Riding 2010; Akkerman et al. 2014). Most of the existing studies using these items focus on the Americas (Hawkins and Riding 2010; Hawkins et al. 2012). As for Europe, there is currently only one published study employing similar items, which focuses on the Netherlands (Akkerman et al. 2014). Other studies examining populist attitudes in the European context typically use alternative items and have a limited country- or region-specific focus. Examples include studies of Slovakia (Stanley, 2011) and Flanders (Elchardus and Spruyt 2016), and of a single party, such as UKIP in the UK (Ford et al. 2012).

Concerning the results of these studies, Hawkins et al. (2012), Elchardus and Spruyt (2016) and Akkerman et al. (2014) all find that populist attitudes are quite widespread amongst the national electorates. Several studies go beyond merely assessing the spread of populism amongst citizens, and link populist attitudes to party preferences (vote 
choice). Despite different operationalisations, both the studies of Ford et al. (2012) and Akkerman et al. (2014) find that voters who score high on their respective populism scales are also more likely to support populist parties. Stanley (2011), on the other hand, finds that even though populist attitudes are widespread across the Slovakian electorate, their impact on electoral preferences is limited, particularly compared with more traditional vote predictors such as nationalist and economic attitudes.

\section{EXPLORING THE POLITICAL IMPLICATIONS OF POPULIST ATTITUDES}

While the studies listed above have provided valuable initial insights into the connection between populist attitudes and populist party support, they are somewhat limited as they rely on data from single countries, and often lack inferential evidence. At this moment, we still know little about the extent to which individuals with an affinity for populism prefer populist parties over other parties. Bearing this in mind, using data from multiple European countries, we aim to come to a closer understanding of the motives and attitudes underlying populist party support.

The first question we seek to answer is to what extent populist voters (i.e. individuals with higher levels of populist attitudes) support populist parties, instead of other parties. Building on initial indications from single-country studies focusing on the USA (Hawkins and Riding 2010) and the Netherlands (Akkerman et al. 2014), we hypothesise this to be the case across European countries. After all, seeing how populism appears inherent to democracy (Rovira Kaltwasser 2014b; Huber and Schimpf 2016a; 2016b), both previously mentioned studies on the USA and the Netherlands indicate that their findings could be generalised to other democracies. Just like we would expect individuals with liberal views to support liberal parties and people prone to nationalism to vote for nationalist parties, we argue that individuals with strong populist attitudes presumably support populist parties.

H1: Supporters of populist parties are characterised by stronger populist attitudes than the supporters of more traditional party families.

This initial question forms the foundation for further, more detailed and inferential claims regarding populist attitudes and party preferences. Notably, while we would expect populist attitudes to be stronger amongst populist party supporters, this would 
not in itself provide evidence for the claim that these attitudes also shape populist voters' party preferences. Therefore, our analysis also seeks to gauge the potential electoral value of populism: is it the populist nature of the parties that attracts voters, or can/should we explain their electoral support in different ways? While Akkerman et al. (2014) show a connection between Dutch voters' populist attitudes and their preference for populist parties, we are not able to draw any inferential or substantive conclusions from this. Stanley (2011) does focus on the explanatory power of populist attitudes, finding little evidence that populism is an important vote determinant in Slovakia. Other studies use partial indicators of populism to conclude there is a positive association between certain components of populism and populist party support. For example, Ford et al. (2012) show that dissatisfaction with traditional parties in the UK contributed to a UKIP vote, while Schumacher and Rooduijn (2013) conclude that protest attitudes constitute a significant predictor of populist party support in the Netherlands. Such variables, however, only provide a crude proxy for individual-level sentiments of, or affinity towards, populism.

Overall, the sparse existing literature thus presents ambivalent evidence as to whether populist attitudes can be seen as a potential predictor of (populist) party support. Yet, this question is important if populist attitudes are indeed widespread. Furthermore, more accurate insights into the political implications of populist attitudes would allow us to further examine under which conditions (populist) parties can translate populist potential into (electoral) support. We expect that the strength of populist attitudes provides an individual-level mechanism that determines whether an individual opts for a populist party (in case the individual has strong populist attitudes) or a non-populist party (in case the individual has weak populist attitudes).

H2: The stronger the populist attitudes of an individual, the more likely they are to support a populist party.

Although we expect that populist attitudes stimulate the vote for all populist parties, we suspect the broader opinion structures of their supporters to vary, depending on the wider policy positions of a given populist party. This relates to the notion that populism can be seen as 'chameleonic', or defined as a 'thin-centred' ideology, which makes normative claims about the functioning of democracy, but lacks judgements where it concerns concrete policy areas (see Taggart 2000, 2004; Mudde 2004; Stanley 2008). 
Mudde and Rovira Kaltwasser (2012) argue that populism - as an ideological motivator is in need of a more substantial 'host ideology' to become successful. Parts of existing, more comprehensive, ideologies can and should thus be added to the populist core for populist parties to mobilise. This is largely confirmed by empirical studies that highlight the importance of more policy-oriented considerations as part of populist party preference (cf. Schumacher and Rooduijn 2013; Stanley 2011). This implies that populist party voters are not indifferent about the wider policy agendas of populist parties.

In the European context, populism tends to be associated primarily with parties of the far right and far left (e.g. Mudde 2007; March 2011). The former are primarily characterised by their culturally conservative and authoritarian positions (concerning issues such as immigration and law and order), while the latter focus more on socioeconomic issues and express anti-capitalist views. In our analysis, we therefore separate the supporters of socio-economically left-wing and culturally right-wing populist parties (cf. footnote five), and consider whether populist attitudes still predict political support when we control for the economic position of left-wing populist party supporters and the cultural position of right-wing populist party supporters. At the same time, we do expect that, besides populist attitudes, economically left-leaning issue positions encourage support for a left-wing populist party, while right-wing positions on cultural issues stimulate the support for a right-wing populist party (e.g. Cutts et al. 2011; Ivarsflaten 2008; March \& Rommerskirchen 2015; Ramiro 2016; van der Brug et al. 2005; Visser et al. 2014).

H3a: Left-wing economic issue positions increase the likelihood of supporting a left-wing populist party over any other party.

H3b: Right-wing cultural issue positions increase the likelihood of supporting a rightwing populist party over any other party.

Altogether, we believe that an individual's affinity with populism and agreement with a populist party's issue positions are important contributors to populist party support. At the same time, we doubt that these two mechanisms operate independently from one another, as is often assumed in the literature (e.g. Ivarsflaten 2008; Schumacher and Rooduijn 2013; Stanley 2011). First of all, we recognise that populist attitudes and issue positions may not be equally important party choice mechanisms for all individuals (e.g. Lucassen and Lubbers 2012). In addition, the weight and effect of such mechanisms 
often depends on intervening factors, whose impact varies between individuals (e.g. Hetherington and Globetti 2002; Jacoby 1991; Rudolph and Evans 2005; van der Eijk et al. 2005). Translated to our study, the effect of issue positions on populist party support may well differ between voters, depending on how populist an individual is.

We can further explain our expectations as follows. Even when individuals are attracted by the policies of populist parties, they may still opt for a different party competing on the basis of a similar policy agenda. Differently put, our previously formulated hypotheses $(\mathrm{H} 3 \mathrm{a}-\mathrm{b})$ require some adjustment in order to explain why some individuals opt for a populist party, whereas others do not. While this could simply be related to individual differences in populist attitudes (an additive effect), we theorise that populist attitudes also condition the effect of policy considerations on populist party support. While we expect that policy preferences have an independent effect on populist party support, we further posit that the relationship varies as a function of an individual's populist attitudes.

We argue that this conditional effect can be directly linked to the essence of populism. The antagonistic and dualistic nature of populism allows individuals to fit most policyoriented attitudes within a populist anti-establishment framework. Populist criticism of political elites and politics in general is often centred on perceived policy failure, not the least in areas such as immigration (in case of right-wing populists) or wealth distribution (in case of left-wing populists) (e.g. Mudde 2007; March 2011; van Kessel 2015). With respect to our argument, this implies that while individuals may, for instance, have similar views on socio-economic inequality or immigration, their perception of who is responsible for perceived problems (e.g. the elite) will affect whether they choose a populist party or a more traditional, non-populist party. Differently put, we suggest that policy considerations can serve as populism's 'host ideology', thereby essentially allowing populist attitudes to condition the likelihood that policy considerations result in a populist vote. We then expect that at higher levels of populism, the effect of policy considerations on the populist vote increases.

In sum, we expect that populist attitudes and issue positions do not operate as two independent mechanisms, but rather that populist attitudes condition, and thus moderate, the effect of issue positions on populist party support. When holding issue 
positions constant (at their mean), we expect that individuals with strong populist attitudes show a higher probability to support a populist party than individuals with weak populist attitudes. Vice versa, we expect the average marginal effect of congruous issue positions on populist party support to be positive, even when populist attitudes are at their lowest level. We expect the size of this effect to increase, as populist attitudes grow stronger.

H4a: The stronger populist attitudes become, the stronger the effect of left-wing economic issue positions on the support for left-wing populist parties.

H4b: The stronger populist attitudes become, the stronger the effect of right-wing cultural issue positions on the support for right-wing populist parties.

To recapitulate, we started our study with the specification that populism is not necessarily restricted to the political supply side, but that it can also be found as an attitude amongst citizens. However, the question remains to what extent there is a match between the populist character of parties and the populist attitudes of individuals. We propose to study this using a threefold analysis. First, we describe the characteristics and opinion structures of populist party supporters, and consider in particular whether these individuals are characterised by above-average levels of populist attitudes. Second, by means of a unique cross-sectional research design we determine which factors correlate with populist party support, considering in particular populist attitudes and issue positions. Third, we examine whether there is a conditional association between issue positions and populist attitudes when explaining populist party support.

\section{DATA, INSTRUMENTS AND METHOD}

We use data from an original cross-national survey $(\mathrm{n}=18,368)$ that was conducted between June and August of 2015 as part of the LIVEWHAT project. ${ }^{2}$ The dataset includes nationally representative samples $(\mathrm{n}=+/-2,000)$ of nine European countries (France, Germany, Greece, Italy, Poland, Spain, Switzerland, Sweden, UK). All national samples are quota samples that match national population statistics concerning gender, region, age and educational attainment.

\footnotetext{
2 The project "Living with Hard Times: How Citizens React to Economic Crises and Their Social and Political Consequences" (LIVEWHAT) received funding from the European Union's 7th Framework Programme under grant agreement $n^{\circ} 613237$.
} 


\section{Dependent variable}

To assess the association between populist attitudes and populist party preference, it is necessary to determine which parties fall into the populist category. The recent study of van Kessel (2015) provides a comprehensive overview and identifies the populist parties in Europe that gained parliamentary representation in elections between 2000 and 2013. Parties were considered populist if they consistently '(1) portray[ed] 'the people' as virtuous and essentially homogeneous; (2) advocate[d] popular sovereignty, as opposed to elitist rule; and (3) define[d] themselves against the political establishment, which is alleged to act against the interest of 'the people" (van Kessel 2015: 33).

To include populist parties at the time of the survey, we expand on van Kessel's (2015) initial account. Given the available answer categories of a prospective vote choice variable (election tomorrow), we identify 15 populist parties ${ }^{3}$ : National Front (FN) (France); Alternative for Germany (AfD) and the Left (Linke) (Germany); Five Star Movement (M5S), Forza Italia (FI) and Northern League (LN) (Italy); UK Independence Party (UKIP) and British National Party (BNP) (United Kingdom); Law and Justice (PiS) and Kukiz'15 (Poland); Sweden Democrats (SD) (Sweden); Swiss People’s Party (SVP) (Switzerland); LAOS and SYRIZA (Greece) and Podemos (Spain). ${ }^{4}$

Given that populist parties vary regarding their broader ideological attributes - which certainly also applies to the parties included in our study - it would not be accurate to speak of a single 'populist party family', in the same way as we would refer to a liberal or a socialist party family. In our study, we nevertheless aim to assess whether it is the populist component of these parties that has explanatory value as far as party support is concerned. However, since we also aim to examine the effects of issue positions in a

\footnotetext{
${ }^{3}$ We rely on a prospective vote choice variable because we want to capture current attitudes towards parties and minimise recollection bias. Additionally, the prospective vote variable includes parties like Podemos and M5S, whereas the more traditional retrospective vote variable (last national election) does not. We consider the benefit of these two additional populist parties outweigh the potential criticism scholars might have on our choice of a prospective over a retrospective vote choice variable. Nonetheless, we validate our results by also using the retrospective vote variable as a dependent variable, and our principal conclusions remain the same.

4 The AfD and PiS can be considered borderline cases of populism. The former turned into a more clearcut populist direction only after the 2013 German federal election (cf. Arzheimer 2015; Lewandowsky et al. 2016), whereas the latter can be characterised by varying levels of populism throughout time (van Kessel 2015). As a robustness check, we ran a separate analysis without these parties, and our substantive results remain the same. Other potential populist parties, like the Front de Gauche in France, were not included in the survey's potential answer categories because their relevance was deemed minimal. We provide a basic overview of populist and non-populist party supporters per country in Appendix III (Table III.A).
} 
subsequent step of our analysis, we further distinguish between two main types of populist parties: (culturally) right-wing populist parties and (economically) left-wing populist parties. The first category includes FN, AfD, FI, LN, UKIP, BNP, PiS, Kukiz'15, SD, SVP, and LAOS; the second includes die Linke, M5S, SYRIZA and Podemos. ${ }^{5}$ This categorisation is admittedly rough: the M5S differs from the other leftwing cases in having a more ambiguous, and less socialist, ideological profile; the FI and PiS rely less on nativist appeals in comparison with the other right-wing cases. Since the Italian M5S and FI are the least 'typical' populist left- and right-wing parties, we crossvalidated our results by excluding them from our analysis. The substantive interpretations remained the same.

For the purpose of identifying and comparing the strength of populist attitudes amongst supporters of various types of parties, we operationalise party families based on the prospective vote choice variable and a reduced implementation of the ZEUS party family classification scheme. We slightly changed this to allow for the identification of populist parties, and to compare these to some of the more traditional party families. Overall, we distinguish between the following types of parties: socialists, liberals, Christian democrats, conservatives, right-wing populist parties, left-wing populist parties and 'other' parties.

Independent variables

Conceptually, this study proposes two core explanatory constructs that can influence populist party support: populist attitudes and issue positions. To measure populism, we propose to harmonise eight separate items [see Table 1]. Six of these items stem from the populism items originally developed by Hawkins and Riding (2010), which largely correspond to those used by Akkerman et al. (2014). We select the items that, in the latter study, loaded significantly on the populist dimension (POP1-5, POP7).

\footnotetext{
${ }^{5}$ Certain right-wing populist parties are also characterised by left-wing economic stances (at least in some areas). We choose to classify these parties as primarily right-wing because their cultural positions are most salient and primordial for individuals to support them, while their economic positions often remain secondary (e.g. Minkenberg 2000; Ivarsflaten 2008).

${ }^{6}$ For more information on the classification scheme and further per-country specifications, we refer to Appendix I.
} 
Furthermore, we add two unique items that proved to increase the validity of our populist measure. ${ }^{7}$

[Insert Table 1: Question-wording populism items]

All individual items consist of 5-point Likert scales, with higher values indicating higher levels of populist attitudes (Cronbach's alpha $=0.88) .{ }^{8}$ Since one of our primary assumptions is the existence of manifest populist attitudes at the individual level, we estimate this proposed construct by means of item response theory (IRT). ${ }^{9}$ This particular technique has a number of advantages over the more traditional estimation methods. ${ }^{10}$ Most notably, IRT allows both the concepts of reliability (information) and measurement error to fluctuate across the latent variable, thereby basically increasing measurement accuracy. It is also worth noting that IRT item properties are invariant, meaning that estimated parameters should remain mostly stable in the absence of nonrandom variance, even when the items are fielded amongst different populations.

We also measure issue positions by estimating two separate policy dimensions of the political spectrum. We construct a scale for each dimension, based on CFA estimates. For economic issue positions, we rely on five items asking about equality, competition, taxes and the role of government (Cronbach's alpha $=0.59)$. For cultural issue positions,

\footnotetext{
${ }^{7}$ Van Hauwaert et al (2017) use item response theory and find that (i) items five, seven and eight are the most informative items of a latent populist construct, and (ii) using this particular 8-item scale, while perhaps not the most parsimonious, increases the quality of a populist measurement.

${ }^{8}$ While the (internal) consistency between the responses to our populist items is high, we do not rely on a (weighted) additive or summed index to measure populism. The initial distributions of the items are quite skewed to the right, suggesting a ceiling effect. This would indicate a sizeable loss of variance, particularly at the lower ends of any additive or summed scale (cf. DeVellis 2012). When simply summing items, the issue of latent variable indeterminacy remains (cf. Bollen, 2002). A more careful and extensive IRT analysis of these items further indicates there are substantial within-item differences (information) that would otherwise be lost. Therefore, for these particular items, we warn against using an additive or summed scale when doing inferential research, at the risk of bringing forward inaccurate results that are not able to provide fine distinctions between individuals or groups of individuals.

${ }_{9}^{9} \mathrm{We}$ also test for between-country measurement invariance in the form of differential item functioning (DIF). While such tests are extensive (e.g. Davidov 2009; Davidov et al. 2014; Stegmueller 2011), we rely on three initial tests to justify our cross-national estimation (cf. Millsap 2012). First, we can confirm configural equivalence, meaning our latent models share the same factor structure across countries. Second, we can reject non-uniform DIF (metric non-invariance), i.e. our items are not systematically more related to the latent construct for individuals from one country compared to individuals from another country. Third, we can also partially reject uniform DIF (scalar non-invariance), meaning that only certain items (three out of eight) are systematically more difficult or severe for individuals from one country compared to individuals from another country. Several scholars have indicated partial scalar invariance is sufficient for cross-national comparisons (Byrne et al. 1989; Steenkamp and Baumgartner 1998).

${ }^{10}$ For a detailed overview of scale construction in general and some of the main advantages of IRT more specifically, we refer to Kankaras et al. (2011), Raju et al. (2002) and Reise (1993).
} 
we also rely on five items, mostly regarding authority concerns (Cronbach's alpha = 0.48). Each item is composed of an 11-point answer scale, with higher values indicating either more economically liberal or culturally conservative positions. ${ }^{11}$

We also include a number of control variables that could explain either the cultivation of populist attitudes or populist party support. Seeing how research on populist attitudes is only a recent phenomenon, the literature on populism as such does not provide conclusive evidence for most of these suggested mechanisms. First of all, populist attitudes can serve as an example of grievance theory (cf. Gurr's 1970). Therefore, we include indicators for objective (income) and subjective deprivation, which in the literature have often been correlated with right-wing populist party support in particular (e.g. Rydgren 2012). We could also argue that populist attitudes, and their translation into populist party support, are directly related to different forms of dissatisfaction (Rooduijn et al. 2016). We thus include social and political trust, satisfaction with democracy, and dissatisfaction with how governments handled the economic and immigration crises. Further, populist party voters are often portrayed as uninterested and uninstructed protest voters (Schumacher and Rooduijn 2013; but see van der Brug et al. 2000), so we control for political interest and efficacy. Concerning right-wing populist party support in particular, prejudice towards immigrants often serves as a complementary explanatory mechanism (e.g. Ivarsflaten 2008; Oesch 2008). Hence, we include both economic and cultural prejudice. We further control for partisan affiliation and account for a standard set of socio-demographic variables, namely gender, age, age squared, education, subjective domicile, household size and marital status. ${ }^{12}$

\section{Method}

As respondents are nested within countries, we account for the effects of country-level dynamics using hierarchical logistic modelling (Bryk and Raudenbusch 1992; Hox 2010). The most common approach for this would be multilevel (random effects or mixed)

\footnotetext{
11 When we examine in more detail the distributions of the economic issue positions scale for left-wing populist party supporters $(n=1,847)$ and the cultural issue positions scale for right-wing populist party supporters $(\mathrm{n}=2,527)$, both location (skewness) and variability (kurtosis) measures indicate near-normal distributions. Furthermore, this indicates we can also find important proportions of our sample sizes at the tails of our distributions. For more information on the original items and the question wordings of our independent variables, we refer to Appendix II.

${ }^{12}$ For descriptive statistics of our independent and control variables, we refer to Tables III.A to III.C in Appendix III.
} 
modelling; however, considering we only examine nine countries, this is likely to be problematic. It would restrict the degrees of freedom at the country-level, which in its turn would negate many of the advantages of MLM, and increase omitted variable bias. Combined, this would negatively bias our estimates, as well as their standard errors and their confidence intervals - particularly at the country level (Hox 1998; Stegmueller 2013). Altogether, that would increase the likelihood of level-I errors (cf. Zorn 2001).

We therefore rely on fixed effect models in lieu of multilevel modelling (Steenbergen and Jones 2002; Allison 2009). The fixed effects allow us to control for the effect of countryspecific features on the dependent variable, even when the number of countries remain limited. ${ }^{13}$ Fixed effect modelling has some further particular advantages. For one, given that country-specific error terms are treated as a set of fixed numbers estimated in the model, it becomes irrelevant whether the error terms are independent of other variables. This provides a particular advantage over the assumed normality and independence of country-specific error terms in multilevel modelling (Hox et al. 2010). So, whereas multilevel models risk having biased parameters in case important between-group differences go unmeasured (Chaplin 2003; Clarke et al. 2010; Murnane and Willett 2011), fixed effects models account for general between-group effects (i.e. country-level variability), and thereby reduce omitted variable bias.

\section{EMPIRICAL RESULTS}

Through a descriptive analysis, we first take a closer look at the mean level of populist attitudes found in different prospective party choice categories. Figure 1 allows us to make two notable observations. ${ }^{14}$ First, traditional (mainstream) party supporters appear to hold below-average levels of populist attitudes. This is an expected outcome: traditional parties are typically considered part of the political elite, and are unlikely to attract the support of individuals with strong populist (and thus also anti-elitist) attitudes. Second, left- and right-wing populist parties tend to attract the support from individuals with strong populist attitudes. In other words, we find that individuals with above-

\footnotetext{
13 We have replicated our models by means of simple country-by-country logit models and found similarly significant results. Individual country results can be obtained from the authors upon request.

${ }^{14}$ When we further disaggregate Figure 1 per country, our observations are confirmed [see Table I.C in Appendix I].
} 
average levels of populist attitudes are clearly overrepresented amongst the supporters of populist parties.

[Insert Figure 1: Average estimates of populist attitudes, per party family]

Overall, and in line with the first hypothesis, the differences between traditional and populist party supporters are considerable, and appear to suggest that populist supply meets a populist demand. While this is in line with some of the recent country-specific studies (e.g. Akkerman et al. 2014), we are now able to further confirm this observation cross-nationally.

Figure 1, however, does not reveal anything about the potential effect populist attitudes can have on (populist) party preferences. Through a set of fixed-effects logistic models we therefore examine whether populist attitudes may also motivate individuals to support populist parties. Given that the literature tells us there are likely differences between left- and right-wing populist party voters as far as their policy-related motivations are concerned (Ivarsflaten 2008; Schumacher and Rooduijn 2013; Visser et al. 2014), we provide separate models for left- and right-wing populist party supporters. In other words, we examine whether populist attitudes and issue positions, as well as a number of alternative variables, have a different effect on the probability to support either a left-wing or a right-wing populist party.

In a preliminary step, we only model socio-demographics so as to 'describe' the populist party supporter and provide some insights into his or her identity (models $1 \mathrm{a}-\mathrm{b}$ ). ${ }^{15}$ The results show that left-wing populist party supporters tend to fall into lower income and lower class categories, which can be seen as objective and subjective economic indicators, respectively. While European scholarship typically theorises the connection between populism and class dynamics in studying the populist right (cf. Rydgren 2012), our results suggest that economic indicators also predict the left-wing populist vote. Unlike left-wing populist party supporters, right-wing populist party supporters tend to be male and less educated (cf. Bovens and Wille 2009).

\footnotetext{
${ }^{15}$ For all full models (models 1 to 3), we refer to Appendix IV.
} 
We subsequently include the relevant predictors in a second set of models that also include behavioural variables (models $2 \mathrm{a}-\mathrm{b}$ ). For reasons of clarity, Figure 2 depicts the average marginal effects (AMEs) for both left- and right-wing populist party support. ${ }^{16}$ While we can observe some notable differences between the predictors of the support for the populist left and right, we see that populist attitudes - in both instances - serve as an important predictor. They increase the probability of populist party support, meaning that - translated into odds ratios - for a one unit increase in populist attitudes we expect to see a 35 and 20 per cent increase in the odds of an individual supporting a left- and a right-wing populist party, respectively. While we recognise that the difference between these odds ratios might be partially due to the specific cases included in our study, we find general support for hypothesis 2: the stronger the populist attitudes of an individual, the more likely they are to support a populist party.

[Insert Figure 2: Average marginal effects of models 2a and 2b]

While this finding is not surprising in itself, with our unique and comprehensive operationalisation of populist attitudes we have been able to go beyond the findings in the existing literature. Namely, we are able to distinguish the concept of populist attitudes from political distrust, dissatisfaction with politics or democracy, and protest or anti-establishment feelings by controlling for these alternative mechanisms. In line with some more theoretical accounts, we therefore find evidence suggesting that populist attitudes are a unique empirical construct, and that they have a separate and substantially relevant impact on populist party support (cf. Hawkins 2009).

When we look more closely at some of the alternative mechanisms in Figure 2, two similarities stand out. First, both left- and right-wing populist party supporters are more likely to have higher levels of political interest. We thus posit that populist party supporters are not typically politically apathetic or unaware of political developments. This directly contradicts interpretations of populist party support as the result of a simple protest mechanism for uninformed voters (Hibbing and Theiss-Morse 2002). Furthermore, seeing how it is possible to interpret political interest as a motivational prerequisite for political participation (delli Carpini and Keeter 1997), we can argue that

\footnotetext{
16 We excluded party identification from the coefficient plot because the size of the coefficient is disproportionate (yet significant) with all others.
} 
political interest actively contributes to populist expressions. In short, our results indicate that populist party support may be a purposeful action by politically invested and interested voters.

Second, both left- and right-wing populist party supporters share lower levels of satisfaction with democracy. This finds substantial support throughout the literature and speaks directly to the core of populism, namely as an expression of (political) antipathy and disenfranchisement (Roberts 2006; Webb 2013). Even more, as we noted before, dissatisfaction (with democracy) is even routinely used as a crude proxy for populism (Ford et al. 2012).

However, beyond this, the two groups of voters mainly show different motivational dynamics. Individuals who are more prejudiced towards immigrants - regardless of whether this has economic or cultural foundations - are more likely to support rightwing populist parties, whereas less prejudiced individuals are more apt to support leftwing populist parties. Similarly, those who are more dissatisfied with how the government handled the immigration crisis are more prone to support right-wing populist parties, and less inclined to support left-wing populist parties.

When we examine the predictive value of issue positions, we find that - generally speaking - policy matters for populist party supporters (March and Rommerskirchen 2015; Schumacher and Rooduijn 2013; van Kessel 2015). We do observe important differences between left- and right-wing populist party supporters. Individuals who are culturally left leaning (liberal) are more likely to support a left-wing populist party, while those who are more authoritarian are more likely to support a right-wing populist party. At the same time, while left-wing economic issue positions contribute to the likelihood of left-wing populist party support, we cannot draw any conclusions regarding the economic preferences of right-wing populist party supporters. We recognise this might be due to the composition of the 'right-wing populist' category, which comprises a mixture of economically liberal (e.g. FI) and more protectionist (e.g. FN; PiS) parties. Alternatively, this finding could also indicate that economic issues are of secondary importance to most populist (radical) right-wing voters (e.g. Ivarsflaten 2008). 
Taken together, the findings support hypotheses 3a-b: individuals with left-wing economic issue positions are more likely to support left-wing populist parties - although we also find that culturally liberal issue positions contribute to populist left-wing party preference - while individuals with authoritarian preferences and anti-immigrant attitudes are more likely to support right-wing populist parties. Altogether, these findings demonstrate that, besides populist attitudes, populist parties' policy positions are also relevant when explaining populist party support in a cross-national setting.

[Insert Table 2: Fixed-effects models for populist party support, with interaction terms]

The theory previously outlined in this study suggests that, in addition to their independent effects, populist attitudes condition (moderate) the effect of issue positions on populist party support. We expected to find positive interaction terms for both leftand right-wing populist party support. Table 2, however, returns some inconsistent evidence regarding our hypotheses.

On the one hand, we find initial evidence in support of hypothesis 4a. The statistically significant interaction term indicates that populist attitudes condition (moderate) the effect of economic issue positions on the support for left-wing populist parties. On the other hand, we do not find evidence that populist attitudes condition the relationship between cultural issue positions and the support for a right-wing populist party. Without further analysis, this leads us to conclude that policy- and populist mechanisms both have distinct and separate explanatory power for right-wing populist party support, but also that, inconsistent with hypothesis $4 \mathrm{~b}$, there is no evidence of an interaction effect between the two mechanisms.

[Insert Figures 3a-b: The interaction between populist attitudes and issue positions for left-wing populist party support]

When we consider our results more closely, however, we have to abandon our theoretical expectations pertaining to both hypotheses $4 \mathrm{a}$ and $4 \mathrm{~b}$. We expected strong populist attitudes to strengthen mainly the effect of left-wing economic positions on the support for left-wing populist parties, on the one hand, and the effect of right-wing cultural positions on the support for right-wing populist parties, on the other. Our results, however, suggest there is quite a different mechanism at work. We elaborate on this by 
visualising both interaction terms by means of their average marginal affects (AMEs) and their predicted probabilities.

Figure 3a shows the AME of economic policy preferences on the probability to support a left-wing populist party, and indicates variation in effect size across the full range of populist attitudes. The initial effect of economic policy preferences is negative when populist attitudes are low, but the upward slope suggests the AME goes to zero when populist attitudes increase. While the average marginal effect remains negative, it decreases in magnitude for individuals with higher levels of populist attitudes. This indicates that as an individual becomes more populist, his or her economic policy preferences will play less of a role when supporting a left-wing populist party.

The results thus show that populist attitudes moderate the effect of economic policy preferences on the support for left-wing populist parties, but not exactly in line with our theoretical expectations. To assess more precisely the mechanism at work, we also plot the predicted probabilities for the range of economic policy preferences. Figure $3 \mathrm{~b}$ illustrates that the effect of economic preferences on left-wing populist party support is conditional on populist attitudes. ${ }^{17}$ It reveals that for those with left-wing economic preferences (the upper line), strong populist attitudes do not significantly increase the likelihood of supporting a left-wing populist party. For the other two levels, more centrist and right-wing economic policy preferences, the effect behaves as expected: an increase in populist attitudes significantly increases the probability to support a left-wing populist party.

Thus, these findings suggest that the observed conditional effect is particularly (or only) existent when an individual is characterised by more economically moderate or rightwing economic preferences. This is interesting as it can contribute to explaining why some voters with economically moderate or right-wing policy preferences support a leftwing populist party. Our findings suggest that, despite the incongruence between

\footnotetext{
17 Since it is difficult to visualise an interaction between two continuous variables, we choose to show three interesting levels of policy preferences, namely the mean minus two standard deviations (left-wing economic policy preferences), the mean (centrist economic policy preferences) and the mean plus two standard deviations (right-wing economic policy preferences). Further investigations lead us to conclude that populist attitudes only matter for respondents with economic policy preferences greater than two on our 11-point scale (see also Appendix V, Figure V.1).
} 
personal economic policy preferences and the party's economic platform, voters may still prefer a left-wing populist on the basis of their populist attitudes.

Overall, this indicates that populism has the potential to serve as a 'motivational substitute', and does not, as we expected, primarily serve as a reinforcing mechanism for those individuals whose policy preferences are congruous with those of the left-wing populist party. Thus, as the predictive value (probability) of an individual's (left-wing) economic issue position decreases, populist attitudes may serve as an alternative motivational mechanism that helps determine left-wing populist party support. For individuals with more centrist or right-wing socio-economic convictions, strong populist attitudes may still sway such persons to cast a left-wing populist vote. On the other hand, for those individuals who show a limited affinity with populism, economic policy considerations are really what matters when explaining their support for a left-wing populist party. Regardless of their levels of populist attitudes, these respondents will have a relatively consistent probability of endorsing left-wing populist parties based on their issue positions.

[Insert Figures 4a-b: The interaction between populist attitudes and issue positions for right-wing populist party support]

As we initially gathered from Table 2, the interaction term for right-wing populist party support is negative (as expected), but not significant. Yet, to truly get to the bottom of this conditional effect, and subsequently draw accurate inferences, Brambor et al. (2006) suggest plotting the interaction even if its coefficient is not significant (cf. also Berry et al. 2012). After all, the insignificant coefficient in Table 2 only indicates that our interaction effect is not significant on average. The results, illustrated in Figures 4a-b, are very similar to the ones we previously presented concerning left-wing populist party support.

Figure $4 \mathrm{a}$ indicates that, on average, populist attitudes moderate the effect of cultural policy preferences on the support for right-wing populist parties. Similar to Figure 3a, it shows that the AME of cultural policy preferences on the probability to support a rightwing populist party goes to zero as populist attitudes increase. To further clarify this 
general observation, we once again plot the predicted probabilities. ${ }^{18}$ Figure $4 \mathrm{~b}$ indicates that the absolute effect of cultural policy preferences on the predicted probabilities to support a right-wing populist party decreases (i.e. converging predicted probability lines) as populist attitudes increase. Furthermore, when individuals' cultural issue positions are located at the far right of the policy scale (i.e. the upper line in Figure 4b), the statistical effect of populist attitudes on the probability to support a right-wing populist party can no longer be distinguished from zero. In line with our observations for left-wing populist party support, we do not find evidence that populism conditions the effect of policy preferences on right-wing populist party support when an individual's policy preferences are very conservative. Similar to left-wing populist party support, both of these observations reiterate the importance of policy considerations for some voters, and the value of populist attitudes as a 'motivational substitute' for others.

In sum, while we theoretically reject hypotheses $4 \mathrm{a}$ and $4 \mathrm{~b}$, our results do show that - on average and for a large part of respondents - populist attitudes interact with issue positions on populist party support. This effect, however, is opposite to what we expected and is not uniform across our sample. Neither among left- nor right-wing populist party supporters do we find statistical evidence that individuals at the far economic left and far cultural right are motivated mainly by populist attitudes. Instead, they appear primarily policy-driven. At the same time, individuals further removed from these extreme issue positions may still be pulled to the populist party due to their strong populist attitudes. A left-wing populist party may still tempt more economically rightleaning individuals if these are characterised by strong populist attitudes. Vice versa, right-wing populist parties may be able to win the support of certain culturally leftleaning voters, as long as these are strongly populist.

\section{DISCUSSION AND CONCLUSION}

Previous studies have shown that populist party supporters are typically dissatisfied with the political establishment, but also attracted by such parties because of their more concrete policy-related arguments. More research is required, however, to answer the

\footnotetext{
${ }^{18}$ We visualise three interesting levels of policy preferences, namely the mean minus two standard deviations (left-wing cultural policy preferences), the mean (centrist cultural policy preferences) and the mean plus two standard deviations (right-wing cultural policy preferences). Further investigations lead us to conclude that populist attitudes only matter for respondents with cultural policy preferences greater than eight on our 11-point scale (see also Appendix V, Figure V.2).
} 
questions of whether populist party supporters also share populist affinities, and whether populist attitudes can be considered important as a predictive mechanism of the (populist) vote. While existing studies have assessed populist attitudes in several populations across the Americas and Europe (e.g. Flanders, the Netherlands, Slovakia), a cross-national study on this topic is still lacking. What is more, except for one case study of Slovakia (Stanley 2011), the existing literature does not tackle the question of whether populist attitudes can possibly motivate people to support populist parties.

In our study, we aimed to fill these gaps in the literature. We used cross-sectional survey data from nine European countries to perform a cross-national analysis of populist attitudes and issue positions, which we related to populist party support. From our findings, we come to three core conclusions. First, in line with single-country studies, we conclude that populist attitudes are particularly strong amongst the prospective voters of populist parties. Compared with traditional party constituents, the overall levels of populist attitudes among populist party supporters are particularly high.

Second, populist attitudes are significant predictors of the support for both left- and right-wing populist parties. These findings thus suggest that the ideas associated with populism have electoral relevance. This, in turn, implies that it is important to treat populism as an essential element of (i) individuals' behavioural voting mechanisms, and (ii) a populist party's broader ideology. Given that previous studies have indicated that populist attitudes are quite widespread among electorates, supply-side expressions of populism may indeed be of considerable electoral and strategic value.

Third, in line with existing research, we find that policy-oriented preferences or issue positions provide alternative explanatory mechanisms for populist party support. Additionally, we found evidence that populist attitudes interact with issue positions, although not quite in the manner we expected. This applies to both left- and right-wing populist party supporters: the effect of populist attitudes on the support for left- and right-wing populist parties is less pronounced for individuals with strong economically left-leaning and culturally right-leaning preferences, respectively. In other words, populist attitudes matter less (to the point of not mattering at all) as the economic or cultural issue positions of individuals become more extreme, and thus supposedly more congruous with those of populist parties at the fringes of the political spectrum. Our 
findings also suggest that some voters who are further removed from the issue positions of populist parties may still be attracted by these parties if they have strong populist attitudes. This implies that it may be electorally rewarding for a political party to adopt a populist discourse or ideology in an attempt to attract populist individuals who do not necessarily agree with its more concrete policies.

In sum, throughout this study, we make a number of important contributions to the study of populism, as well as the broader linkage between demand- and supply-side politics. First, while our findings are in line with a number of existing studies, we examined the effect of populist attitudes as a comprehensive construct, rather than interpreting populism as mere anti-establishment feelings. In other words, by means of our empirical study, we are able to find support for the argument that populist attitudes are unique and distinct from other behaviours such as protest or dissatisfaction.

Second, we provide evidence that issue positions play an important role in the support for populist parties. This would suggest that traditional and populist electorates are, to a certain extent, driven by similar motivations. This, in turn, implies that populist parties are more than just vehicles for an uninformed and apathetic protest vote. Third, we distinguish between left- and right-wing populist parties and show that there are important differences in the characteristics of their supporters. At the same time, we have found that issue positions and populist attitudes interact in a similar way when explaining the support for left-wing populist parties, on the one hand, and right-wing populist parties, on the other.

Finally, while most existing studies on demand-side populism are limited in their geographical scope or inferential abilities, we have been able to provide a unique crossnational analysis. While we need to be careful with the inferences drawn from this crosssectional design, our initial evidence supports original theoretical claims, and provides cross-national information that should stimulate additional analyses. For one, some of the descriptive analyses in this study indicate heterogeneity in populist attitudes across countries, which certainly provide an interesting scope for further research. We recommend in particular that future research examines to what extent our initial evidence is time- and country-specific. Future studies should also seek to employ broader crosssectional, longitudinal or experimental research designs. This would also demand 
developing further the measurement of core concepts in this study, most notably populist attitudes. 


\section{LIST OF REFERENCES}

Akkerman, A., Mudde, C. \& Zaslove, A. (2014). How Populist Are the People? Measuring Populist Attitudes in Voters. Comparative Political Studies 47(9): 1324-1353.

Albertazzi, D. \& McDonnell, D. (2008). Introduction: The Spectre and the Spectre. In D. Albertazzi \& D. McDonnell (eds), Twenty-First Century Populism. The Spectre of Western European Democracy. Basingstoke: Palgrave MacMillan: 1-11.

Allison, P.D. (2009). Fixed effects regression models. Thousand Oaks, CA: Sage.

Arzheimer, K. (2015). The AfD: Finally a Successful Right-Wing Populist Eurosceptic Party for Germany? West European Politics 38: 535-556.

Aslanidis, P. (2016). Is Populism an Ideology? A Refutation and a New Perspective. Political Studies 64(1S): 88-104.

Bale, T., van Kessel, S. \& Taggart, P. (2011). Thrown around with abandon? Popular understandings of populism as conveyed by the print media: a UK case study. Acta Politica 46(2): 111-131.

Bollen, K.A. (2002). Latent variables in psychology and the social sciences. Annual review of psychology 53(1): 605-634.

Bovens, M. \& Wille, A. (2009). Diploma Democracy: On the Tensions Between Meritocracy and Democracy. Utrecht: NWO.

Bryk, A.S. \& Raudenbush, S.W. (1992). Hierarchical Linear Models in Social and Behavioral Research: Applications and Data Analysis Methods. Newbury Park, CA: Sage Publications.

Bulmer, M.G. (1979). Principles of Statistics. Mineola, NY: Dover Publications.

Byrne, B.M., Shavelson, R.J. \& Muthén, B.O. (1989). Testing for the equivalence of factor co-variance and mean structures: The issue of partial measurement invariance. 
Psychological Bulletin 105: 456-466.

Berry, W.D., Golder, M. \& Milton, D. (2012). Improving Tests of Theories Positing Interaction. The Journal of Politics 74(3): 653-671.

Brambor, T., Roberts Clark, W. \& Golder, M. (2005). Understanding Interaction Models: Improving Empirical Analyses. Political Analysis 14(1): 63-82.

Canovan, M. (1981). Populism, New York and London: Harcourt Brace Jovanovich.

Chaplin, D. (2003). Hierarchical linear models: Strengths and weaknesses. Paper presented at the annual meeting of the Association for Public Policy Analysis and Management, Washington, DC, December $9^{\text {th }} 2003$.

Clarke, P., Crawford, C., Steele, F. \& Vignoles, A. (2010). The choice between fixed and random effects models: Some considerations for educational research. IZA Discussion Paper Series 5287. Bonn, Germany: Institute for the Study of Labor.

Cutts, D., Ford, R. \& Goodwin, M. (2011). Anti-immigrant, politically disaffected or still racist after all? Examining the attitudinal drivers of extreme right support in Britain in the 2009 European elections. European Journal of Political Research 50(3): 418-440.

Davidov, E. (2009). Measurement equivalence of nationalism and constructive patriotism in the ISSP: 34 countries in a comparative perspective. Political Analysis 17(1): 64-82.

Davidov, E., Dülmer, H., Schlüter, E., Schmidt, P. \& Meuleman, B. (2012). Using a multilevel structural equation modeling approach to explain cross-cultural measurement noninvariance. Journal of Cross-Cultural Psychology 43(4): 558-575.

DeVellis, R.F. (2012). Scale development: theory and applications. London: SAGE Publications.

Elchardus, M. \& Spruyt, B. (2016). Populism, Persistent Republicanism and Declinism: An Empirical Analysis of Populism as a Thin Ideology. Government and Opposition 51(1): 111-133. 
Ford, R., Goodwin, M. \& Cutts, D. (2012). Strategic Eurosceptics and Polite Xenophobes: Support for the United Kingdom Independence Party (UKIP) in the 2009 European Parliament Elections. European Journal of Political Research 51(2): 204-234.

Hawkins, K. (2009). Is Chavez Populist? Measuring Populist Discourse in Comparative Perspective. Comparative Political Studies 42(8): 1040-1067.

Hawkins, K. A., \& Riding, S. (2010). Populist attitudes and their correlates among citizens: Survey evidence from the Americas. Prepared for the ECPR Workshop Disassembling Populism (and Putting It Back Together Again): Collaborative Empirical Research on Interactions among Populism's Attributes'.

Hawkins, K., Riding, S. \& Mudde, C. (2012). Measuring populist attitudes. Political Concepts Committee on Concepts and Methods Working Paper Series 55: 1-35.

Hetherington, M.J. \& Globetti, S. (2002). Political trust and racial issue positions. American Journal of Political Science 46(2): 253-275.

Hibbing, J.R., \& Theiss-Morse, E. (2002). Stealth democracy: Americans' beliefs about how government should work. Cambridge: Cambridge University Press.

Hox, J.J. (2010). Multilevel analysis. Techniques and applications, $2^{\text {nd }}$ edition. New York, NY: Routledge (Quantitative methodology series).

Hox, J.J., Moerbeek, M. \& van de Schoot, R. (2010). Multilevel analysis: Techniques and applications. Oxon: Routledge.

Huber, R.A. \& Schimpf, C.H. (2016a). Friend or Foe? Testing the Influence of Populism on Democratic Quality in Latin America. Political Studies 64(4): 872-889.

Huber, R.A., \& Schimpf, C.H. (2016b). A drunken guest in Europe? Zeitschrift Für Vergleichende Politikwissenschaft 10(2): 103-129. 
Ionescu, G. \& Gellner, E. (eds.) (1969). Populism, its Meanings and National Characteristics. London: Weidenfeld and Nicolson.

Ivarsflaten, E. (2008). What Unites the Populist Right in Western Europe? Reexamining Grievance Mobilization Models in Seven Successful Cases. Comparative Political Studies 41(1): 3-23.

Jacoby, W.G. (1991). Ideological identification and issue attitudes. American Journal of Political Science 35(1): 178-205.

Jagers, J. \& Walgrave, S. (2007). Populism as Political Communication Style: An Empirical Study of Political Parties' Discourse in Belgium. European Journal of Political Research 46(3): 319-345.

Kankaras, M., Vermunt, J.K. \& Moors, G. (2011). Measurement Equivalence of Ordinal Items: A Comparison of Factor Analytic, Item Response Theory, and Latent Class Approaches. Sociological Methods \& Research 40(2): 279-310.

Kazin, M. (1998). The Populist Persuasion: American History, $2^{\text {nd }}$ edition. Ithaca: Cornell University Press.

Lewandowsky, M., Giebler, H. \& Wagner, A. (2016). Rechtspopulismus in Deutschland. Eine empirische Einordnung der Parteien zur Bundestagswahl 2013 unter besonderer Berücksichtigung der AfD. PVS Politische Vierteljahreschrift 57(2): 247-275.

Lubbers, M., Gijsberts, M. \& Scheepers, P. (2002). Extreme Right-Wing Voting in Western Europe, European Journal of Political Research 41(3): 345-378.

Lucassen, G., \& Lubbers, M. (2012). Who fears what? Explaining far-right-wing preference in Europe by distinguishing perceived cultural and economic ethnic threats. Comparative Political Studies 45(5): 547-574.

March, L. (2011). Radical Left Parties in Europe. Oxon: Routledge. 
March, L. \& Rommerskirchen, C. (2015). Out of left field? Explaining the variable electoral success of European radical left parties. Party Politics 21(1): 40-53.

Millsap, R.E. (2012). Statistical approaches to measurement invariance. New York, NY: Routledge.

Minkenberg, M. (2000). The renewal of the radical right: between modernity and antimodernity. Government \& Opposition 35(2): 170-188.

Moffitt, B. \& Tormey, S. (2013). Rethinking Populism: Politics, Mediatisation and Political Style. Political Studies 62(2): 381-397.

Mudde, C. (2004). The Populist Zeitgeist. Government and Opposition 39(4): 542-563.

Mudde, C. (2007). Populist Radical Right Parties in Europe. Cambridge: Cambridge University Press.

Mudde, C. \& Rovira Kaltwasser, C. (eds.) (2012). Populism in Europe and the Americas. Threat or Corrective for Democracy? Cambridge: Cambridge University Press.

Mudde, C. \& Rovira Kaltwasser, C. (2013). Populism. In: M. Freeden, M. Stears \& L. Tower Sargent (eds.), The Oxford Handbook of Political Ideologies. Oxford: Oxford University Press: 493-512.

Murnane, R. \& Willet, J. (2011). Methods matter. New York, NY: Oxford University Press.

Oesch, D. (2008). Explaining Workers' Support for Right-Wing Populist Parties in Western Europe: Evidence from Austria, Belgium, France, Norway and Switzerland. International Political Science Review 29(3): 349-373.

Pauwels, T. (2011). Measuring populism: A quantitative text analysis of Party Literature in Belgium. Journal of Elections, Public Opinion and Parties 21(1): 97-119.

Pirro, A.L.P. (2014). Digging into the breeding ground: insights into the electoral 
performance of populist radical right parties in Central and Eastern Europe. East European Politics 30(2): 246-270.

Raju, N.S., Laffitte, L.J. \& Byrne, B.M. (2002). Measurement Equivalence: A Comparison of Methods based on Confirmatory Factor Analysis and Item Response Theory. Journal of Applied Psychology 87(3): 517-529.

Ramiro, L. (2016). Support for radical left parties in Western Europe: Social background, ideology and political orientations. European Political Science Review 8(1): 1-23.

Reise, S.P., Widaman, K.F. \& Pugh, R.H. (1993). Confirmatory Factor Analysis and Item Response Theory: Two Approaches for Exploring Measurement Invariance. Psychological Bulletin 114(3): 552-566.

Roberts, K. (2006). Populism, Political Conflict, and Grass-Root Organisation in Latin America. Comparative Politics 38(2): 127-148.

Rooduijn, M., de Lange, S. \& van der Brug, W. (2014). A Populist Zeitgeist? Programmatic Contagion by Populist Parties in Western Europe. Party Politics 20(4): 563 575.

Rooduijn, M., van der Brug, W. \& de Lange, S. (2016). 'Expressing or fuelling discontent? The relationship between populist voting and political discontent. Electoral Studies 43: 32-40.

Rovira Kaltwasser, C. (2014a). Latin American Populism: Some Conceptual and Normative Lessons: Latin American Populism. Constellations 21(4): 494-504.

Rovira Kaltwasser, C. (2014b). The Responses of Populism to Dahl's Democratic Dilemmas. Political Studies 62(3): 470-87.

Rudolph, T.J., \& Evans, J. (2005). Political trust, ideology, and public support for government spending. American Journal of Political Science 49(3): 660-671. 
Sartori, G. (1991). Comparing and Miscomparing. Journal of Theoretical Politics 3(3): $243-$ 257.

Schumacher, G. \& Rooduijn, M. (2013). Sympathy for the "devil"? Voting for populists in the 2006 and 2010 Dutch general elections. Electoral Studies 32(1): 124-133.

Spruyt, B. (2014). An asymmetric group relation? An investigation into public perceptions of education-based groups and the support for populism. Acta Politica 49(2): 123-143.

Stanley, B. (2008). The Thin Ideology of Populism. Journal of Political Ideologies 13(1): 95110.

Stanley, B. (2011). Populism, nationalism, or national populism? An analysis of Slovak voting behavior at the 2010 parliamentary election. Communist and Post-Communist Studies 44: $257-270$.

Steenbergen, M.R. \& Jones, B.S. (2002). Modeling multilevel data structures. American Journal of Political Science 46(1): 218-237.

Steenkamp, J.E.M. and Baumgartner, H. (1998). Assessing measurement invariance in cross- national consumer research. Journal of Consumer Research 25: 78-90.

Stegmueller, D. (2011). Apples and oranges? The problem of equivalence in comparative research. Political Analysis 19(4): 471-487.

Stegmueller, D. (2013). How many countries for multilevel modeling? A comparison of frequentist and Bayesian approaches. American Journal of Political Science 57(3): 748-761.

Taggart, P. (2000). Populism. Buckingham: Open University Press.

Učeň, P. (2007). Parties, Populism, and Anti-Establishment Politics in East Central Europe. SAIS Review 27(1): 49-62. 
van der Brug, W. (2003). How the LPF Fuelled Discontent: Empirical Tests of Explanations of LPF Support. Acta Politica 38(1): 89-106.

van der Brug, W., Fennema, M. \& Tillie, J. (2000). Anti-Immigrant Parties in Europe: Ideological or Protest Vote? European Journal of Political Research 37(1): 77-102.

van der Brug, W., Fennema, M. \& Tillie, J. (2005). Why Some Anti-Immigrant Parties Fail and Others Succeed: A Two-Step Model of Aggregate Electoral Support. Comparative Political Studies 38: 537-573.

van der Eijk, C., Schmitt, H. \& Binder, T. (2005). Left-Right Orientations and Party Choice. In: J. Thomassen (ed), The European voter: a comparative study of modern democracies. Oxford: Oxford University Press.

Van Hauwaert, S.M., Schimpf, C.H. \& Azevedo, F. (2017). The measurement of populist attitudes across Europe: Developing a cross-national scale using item response theory. Paper presented at the ECPR General Conference, Charles University, Prague (Czech Republic), September 6-9, 2016.

van Kessel, S. (2014). The Populist Cat-Dog. Applying the Concept of Populism to Contemporary European Party Systems. Journal of Political Ideologies 19(1): 99-118.

van Kessel, S. (2015). Populist parties in Europe: Agents of discontent? Basingstoke: Palgrave Macmillan.

Visser, M., Lubbers, M., Kraaykamp, G. \& Jaspers, E. (2014). Support for radical left ideologies in Europe. European Journal of Political Research 53(3): 541-558.

Ware, A. (2002). The United States: Populism as Politics Strategy. In Y. Meny \& Y. Surel (eds), Democracies and the Populist Challenge. Basingstoke: Palgrave: 101-119.

Weyland, K. (2001). Clarifying a Contested Concept - Populism in the Study of Latin American Politics. Comparative Politics 34(1): 1-22. 
Table 1: Question wording populism items

\begin{tabular}{cl}
\hline $\begin{array}{c}\text { LIVEWHAT } \\
\text { items }\end{array}$ & \multicolumn{1}{c}{ Description } \\
\hline popatt1 & The politicians in [country] need to follow the will of the people \\
popatt2 & The people, and not politicians, should make our most important policy decisions \\
popatt3 & $\begin{array}{l}\text { The political differences between the elite and the people are larger than the } \\
\text { differences among the people }\end{array}$ \\
popatt4 & I would rather be represented by a citizen than by a specialised politician \\
popatt5 & Elected officials talk too much and take too little action \\
popatt6 & $\begin{array}{l}\text { What people call "compromise" in politics are really just selling out one's } \\
\text { principles. }\end{array}$ \\
popatt7 & $\begin{array}{l}\text { The particular interests of the political class negatively affect the welfare of } \\
\text { the people }\end{array}$ \\
popatt8 & Politicians always end up agreeing when it comes to protecting their privileges. \\
\hline
\end{tabular}


Table 2: Fixed-effect logistic models, with interaction terms

\begin{tabular}{|c|c|c|c|c|c|}
\hline & & Coef. & $\begin{array}{l}\text { Std. } \\
\text { Err. }\end{array}$ & OR & $\begin{array}{l}\text { Std. } \\
\text { Err. }\end{array}$ \\
\hline \multirow{4}{*}{$\begin{array}{l}\text { left-wing } \\
\text { populist } \\
\text { support } \\
\text { (model 3a) }\end{array}$} & $\begin{array}{l}\text { cultural policy preferences } \\
\text { (left-right) }\end{array}$ & -.122 & $\begin{array}{l}(.018)^{* *} \\
*\end{array}$ & .885 & $\begin{array}{l}(.016)^{* *} \\
*\end{array}$ \\
\hline & $\begin{array}{l}\text { economic policy } \\
\text { preferences (left-right) }\end{array}$ & -.169 & $\begin{array}{l}(.018)^{* *} \\
*\end{array}$ & .844 & $\begin{array}{l}(.015)^{* *} \\
*\end{array}$ \\
\hline & populist attitudes & .022 & $(.108)$ & 1.022 & $(.842)$ \\
\hline & $\begin{array}{l}\text { economic left-right \# } \\
\text { populist attitudes }\end{array}$ & .049 & $(.017)^{* *}$ & 1.051 & $(.018)^{* *}$ \\
\hline \multirow{4}{*}{$\begin{array}{l}\text { right-wing } \\
\text { populist } \\
\text { support } \\
\text { (model 3b) }\end{array}$} & $\begin{array}{l}\text { cultural policy preferences } \\
\text { (left-right) }\end{array}$ & .153 & $\begin{array}{l}(.015)^{* *} \\
*\end{array}$ & 1.166 & $\begin{array}{l}(.017)^{* *} \\
*\end{array}$ \\
\hline & $\begin{array}{l}\text { economic policy } \\
\text { preferences (left-right) }\end{array}$ & .010 & $(.014)$ & 1.010 & $(.472)$ \\
\hline & populist attitudes & .314 & $\begin{array}{l}(0.094)^{*} \\
* *\end{array}$ & 1.369 & $\begin{array}{l}(.129)^{* *} \\
*\end{array}$ \\
\hline & $\begin{array}{l}\text { cultural left-right \# populist } \\
\text { attitudes }\end{array}$ & -.022 & $(.014)$ & .978 & $(.014)$ \\
\hline
\end{tabular}

Note: OR = Odds Ratios (see Appendix IV, Table IV.2 for full models); Standard errors in parentheses; *** $\mathrm{p}<0.001, * * \mathrm{p}<0.01, * \mathrm{p}<0.05$. 
Figure 1: Average IRT estimation of populist attitudes, per party family

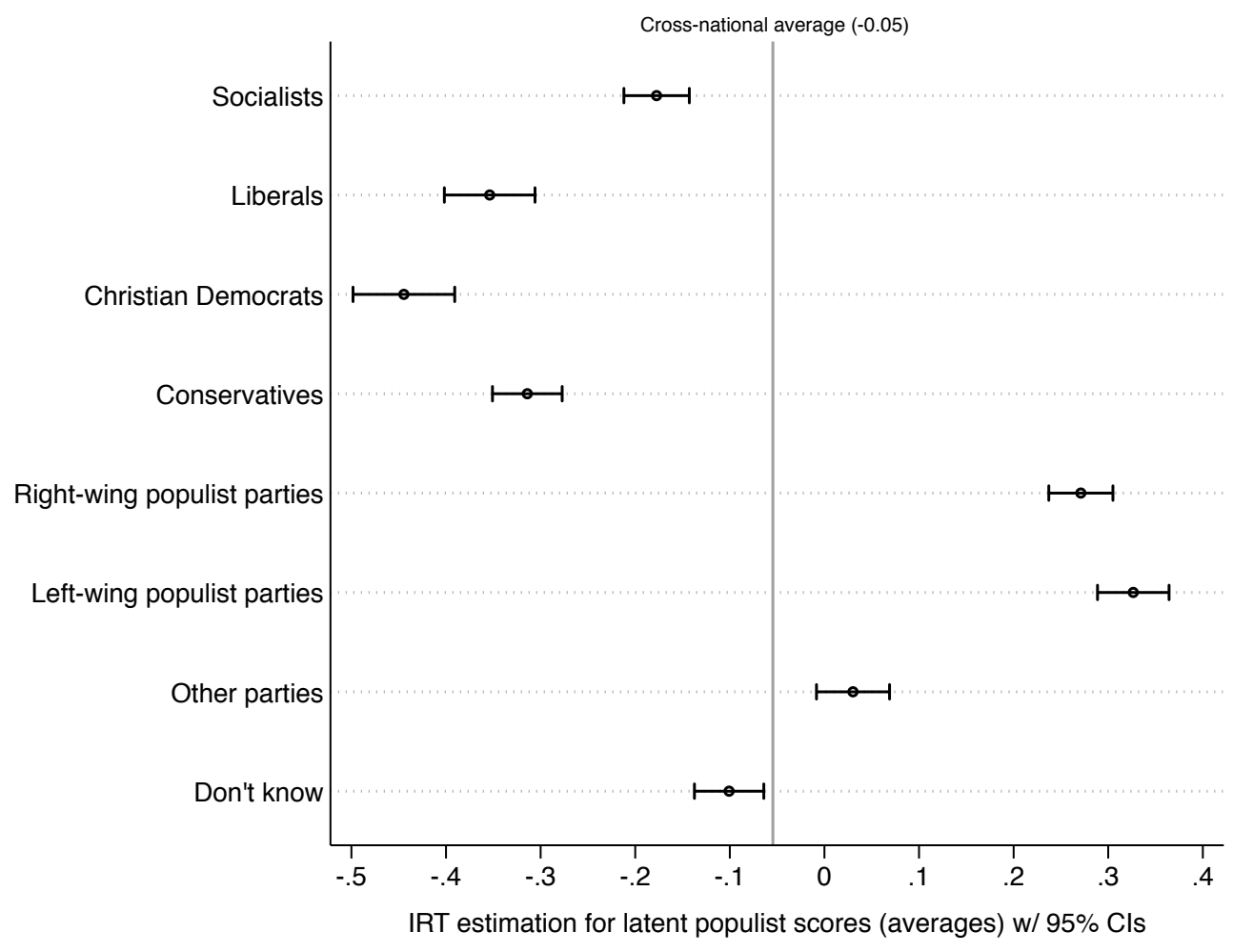


Figure 2: Average marginal effects for models $2 a$ and $2 b$
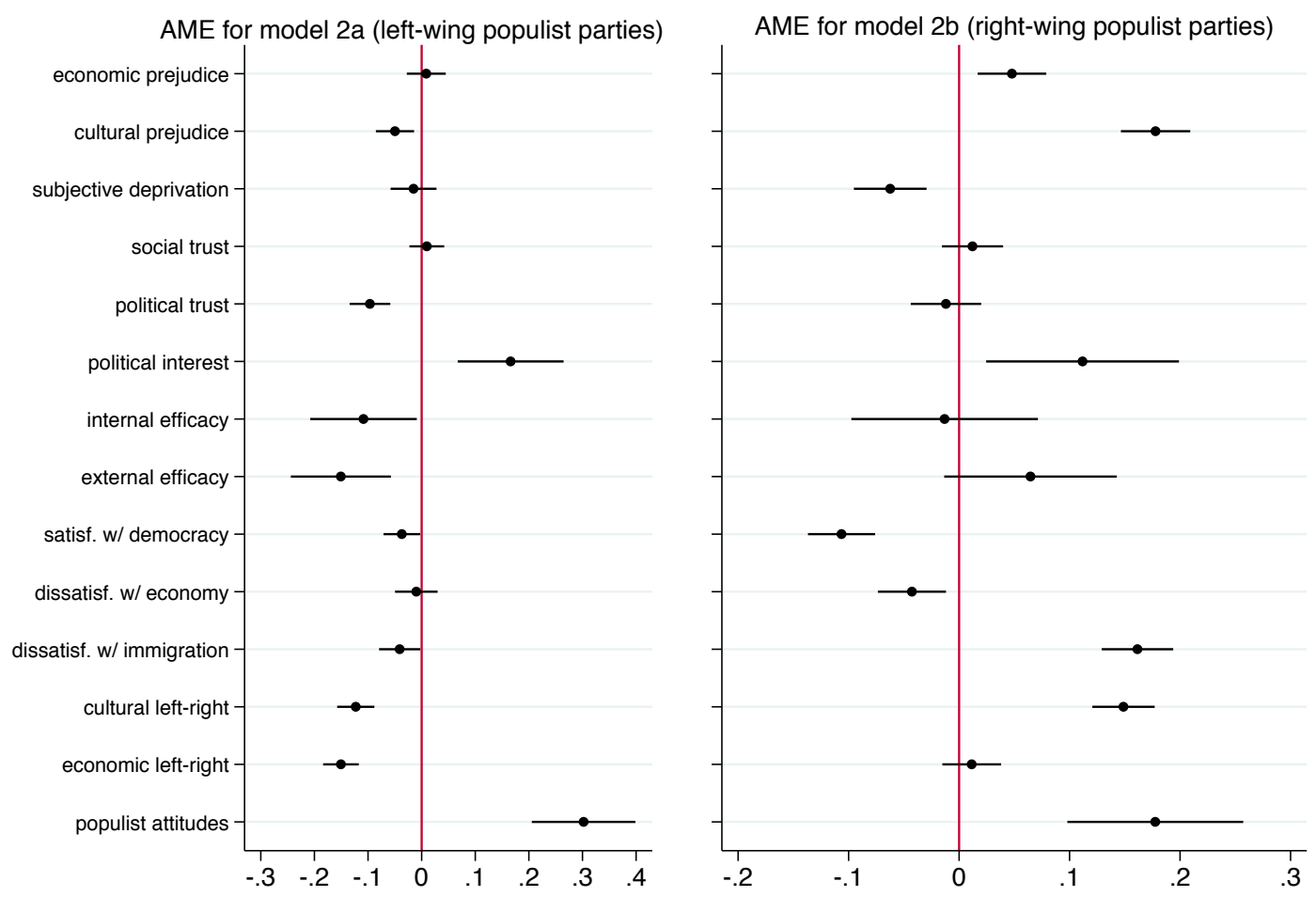

Note: For visual clarity reasons, we did not include party identification or the socio-demographic control variables in the Figure. For full models, we refer to Appendix IV, Table IV.1. 
Figures 3a-b: The interaction between populist attitudes and issue positions for left-wing populist voters
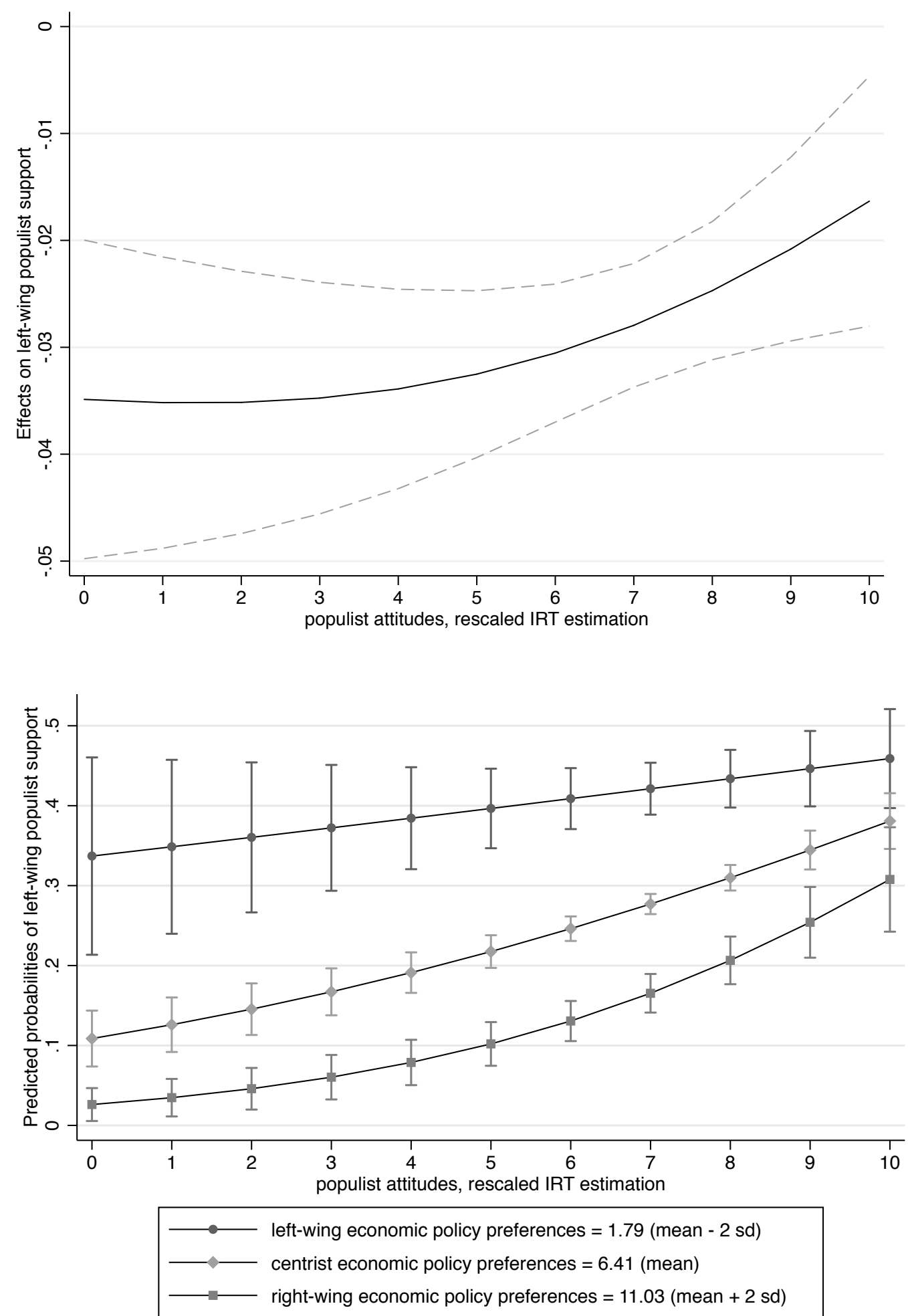

Note: While researchers most commonly put the moderator on the $\mathrm{x}$-axis, we recognise this can be a matter of taste or preferences. With that in mind, we include the marginal effect plots with policy preferences on the $\mathrm{x}$-axis in Appendix $\mathrm{V}$. These plots further confirm and illustrate our findings.

Note: The graph represents the average marginal effect of economic policy preferences on the likelihood to support a left-wing populist party. 
Figures 4a-b: The interaction between populist attitudes and issue positions for right-wing populist voters
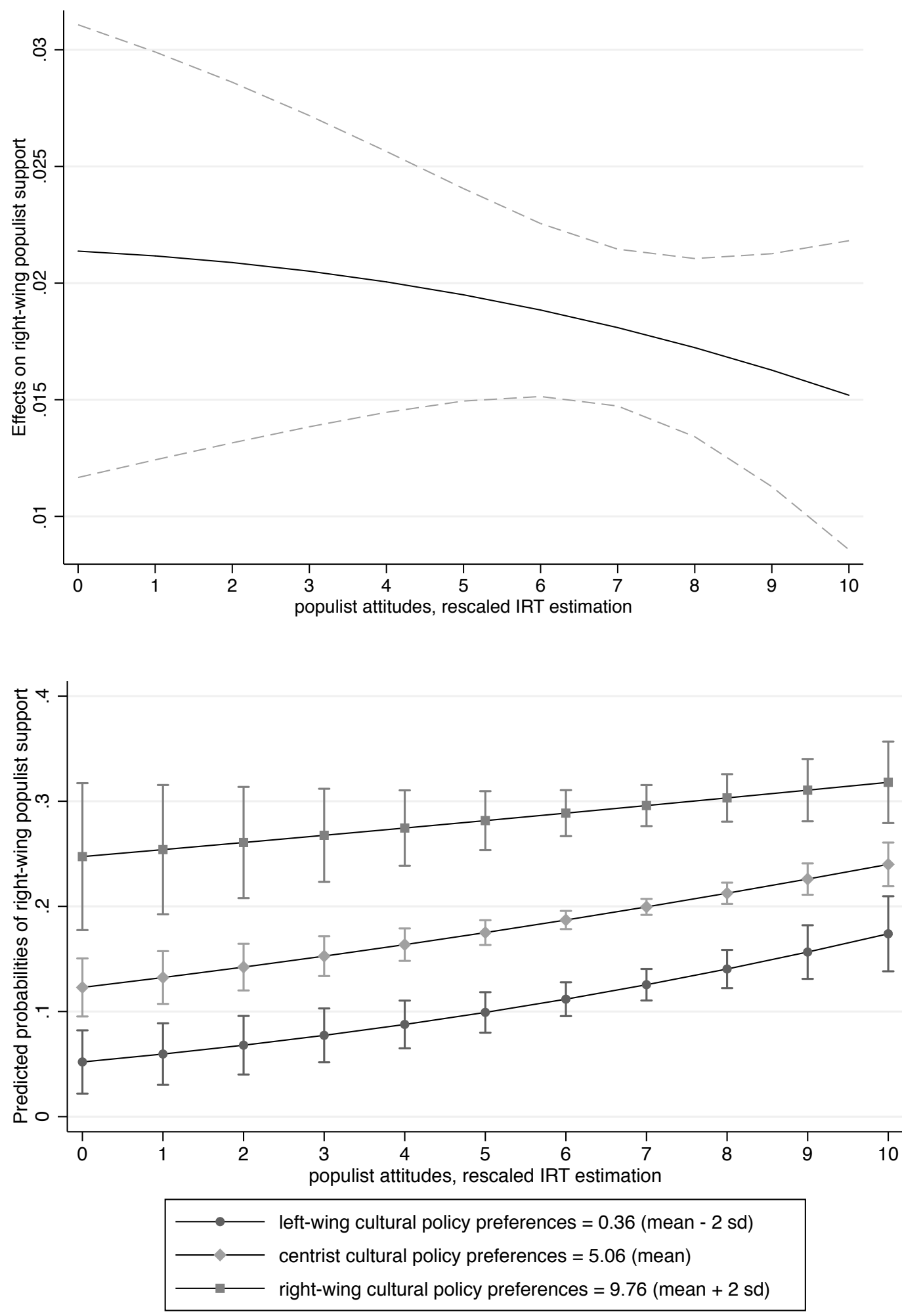

Note: While researchers most commonly put the moderator on the $\mathrm{x}$-axis, we recognise this can be a matter of taste or preferences. With that in mind, we include the marginal effect plots with policy preferences on the $\mathrm{x}$-axis in Appendix V. These plots further confirm and illustrate our findings.

Note: The graph represents the average marginal effect of cultural policy preferences on the likelihood to support a right-wing populist party. 
Appendix I: Party family classification

Table I.A: National parties per party family

\begin{tabular}{|c|c|c|c|}
\hline & party family & country & party \\
\hline \multirow[t]{12}{*}{1} & Socialists & France & PS: Parti Socialiste \\
\hline & & France & PRG: Parti Radical de Gauche \\
\hline & & Germany & SPD - Sozialdemokratische Partei Deutschlands \\
\hline & & Greece & PASOK \\
\hline & & Greece & To Potami (The River) \\
\hline & & Greece & Kinima Dimokraton Sosialiston \\
\hline & & Italy & Partito Democratico \\
\hline & & Poland & SLD — Sojusz Lewicy Demokratycznej \\
\hline & & Poland & Twój Ruch \\
\hline & & Spain & PSOE - Partido Socialista Obrero Español \\
\hline & & Switzerland & Parti socialiste (PS) \\
\hline & & UK & Labour \\
\hline \multirow[t]{11}{*}{2} & Liberals & Germany & FDP - Freie Demokratische Partei \\
\hline & & Italy & $\begin{array}{l}\text { Unione Democratici di Centro e Nuovo Centro } \\
\text { Destra }\end{array}$ \\
\hline & & Poland & Nowoczesna PL \\
\hline & & Spain & Ciudadanos \\
\hline & & Spain & UPyD - Unión Progreso y Democracia \\
\hline & & Spain & CiU - Convergència i Unió \\
\hline & & Sweden & Centerpartiet \\
\hline & & Sweden & Folkpartiet liberalerna \\
\hline & & Sweden & Socialdemokraterna \\
\hline & & Switzerland & Libéraux-Radicaux (PLR) \\
\hline & & UK & Liberal Democrat \\
\hline \multirow[t]{4}{*}{3} & $\begin{array}{l}\text { Christian } \\
\text { democrats }\end{array}$ & France & MoDeM: Mouvement Démocrate \\
\hline & & Germany & $\mathrm{CDU} / \mathrm{CSU}$ \\
\hline & & Greece & New Democracy \\
\hline & & Poland & Kristdemokraterna \\
\hline
\end{tabular}




\begin{tabular}{|c|c|c|c|}
\hline & & Switzerland & Parti démocrate-chrétien (PDC) \\
\hline & & Switzerland & Parti évangélique Suisse (PEV) \\
\hline \multirow[t]{8}{*}{4} & Conservatives & France & UMP: Union pour un mouvement populaire \\
\hline & & France & MPF: Mouvement Pour la France \\
\hline & & Italy & Fratelli d'Italia \\
\hline & & Poland & PO — Platforma Obywatelska \\
\hline & & Spain & PP - Partido Popular \\
\hline & & Sweden & Moderata samlingspartiet \\
\hline & & Switzerland & Parti bourgeois démocratique (PBD) \\
\hline & & UK & Conservative \\
\hline \multirow[t]{10}{*}{5} & $\begin{array}{l}\text { Right-wing } \\
\text { populists }\end{array}$ & France & FN: Front National \\
\hline & & Germany & AfD - Alternative für Deutschland \\
\hline & & Italy & Forza Italia \\
\hline & & Italy & Lega Nord \\
\hline & & Poland & PIS — Prawo i Sprawiedliwość \\
\hline & & Poland & Ruch Pawła Kukiza \\
\hline & & Sweden & Sverigedemokraterna \\
\hline & & Switzerland & Union démocratique du centre (UDC) \\
\hline & & UK & UK Independence Party (UKIP) \\
\hline & & UK & British National Party (BNP) \\
\hline \multirow[t]{4}{*}{6} & $\begin{array}{l}\text { Left-wing } \\
\text { populists }\end{array}$ & Germany & Die Linke \\
\hline & & Greece & SYRIZA \\
\hline & & Italy & Movimento 5 Stelle \\
\hline & & Spain & Podemos \\
\hline \multirow[t]{6}{*}{7} & Other parties & France & EELV: Europe Écologie - Les Verts \\
\hline & & Germany & $\begin{array}{l}\text { NPD - Nationaldemokratische } \quad \text { Partei } \\
\text { Deutschlands }\end{array}$ \\
\hline & & Germany & Piratenpartei \\
\hline & & Germany & Bündnis 90/Die Grünen \\
\hline & & Greece & Golden Dawn \\
\hline & & Greece & $\mathrm{KKE}$ \\
\hline
\end{tabular}




\begin{tabular}{|l|l|l|l|}
\hline & & Italy & Sinistra Ecologia e Libertà \\
\hline & & Italy & Radicali Italiani \\
\hline & & Poland & PSL - Polskie Stronnictwo Ludowe \\
\hline & & Poland & Miljöpartiet de gröna \\
\hline & & Spain & ERC - Esquerra Republicana de Catalunya \\
\hline & & Spain & IU - Izquierda Unida \\
\hline & & Sweden & Vänsterpartiet \\
\hline & & Switzerland & Parti Suisse du Travail (PST) \\
\hline & & Switzerland & Parti vert'libéral (PVL) \\
\hline & & UK & Green Party \\
\hline
\end{tabular}

Note: The original ZEUS classification includes communist parties, socialists, liberals, Christian democrats, conservatives, extreme right and nationalist parties, regionalist parties, environmentalist parties, agricultural parties and 'other' parties. We reduce this classification by harmonising communists, regionalists, environmentalists, agricultural and other parties into the category 'other'. We exclude those individuals who indicated they did not know who they would vote for if there were an election tomorrow (coded as missing). Category 8 includes those individuals who did not know for which party they would vote 
Table I.B: Absolute number of party family supporters, per country

\begin{tabular}{|l|l|l|l|l|l|l|l|l|l|}
\hline & $\begin{array}{l}\text { Socia } \\
\text { lists }\end{array}$ & $\begin{array}{l}\text { Liber } \\
\text { als }\end{array}$ & $\begin{array}{l}\text { Chris } \\
\text { tian } \\
\text { dem } \\
\text { ocrat } \\
\text { s }\end{array}$ & $\begin{array}{l}\text { Conser } \\
\text { vatives }\end{array}$ & $\begin{array}{l}\text { Righ } \\
\text { t- } \\
\text { wing } \\
\text { popu } \\
\text { lists }\end{array}$ & $\begin{array}{l}\text { Left- } \\
\text { wing } \\
\text { popu } \\
\text { lists }\end{array}$ & $\begin{array}{l}\text { Othe } \\
\text { parti } \\
\text { es }\end{array}$ & $\begin{array}{l}\text { don't } \\
\text { know }\end{array}$ & Total \\
\hline France & 317 & 0 & 84 & 311 & 392 & 0 & 171 & 303 & 1,578 \\
\hline Germany & 341 & 88 & 464 & 0 & 126 & 251 & 337 & 147 & 1,754 \\
\hline Greece & 132 & 0 & 155 & 0 & 97 & 761 & 445 & 312 & 1,902 \\
\hline Italy & 330 & 24 & 0 & 48 & 341 & 539 & 161 & 297 & 1,740 \\
\hline Poland & 96 & 96 & 0 & 495 & 874 & 0 & 44 & 172 & 1,777 \\
\hline Spain & 272 & 355 & 0 & 300 & 0 & 423 & 239 & 236 & 1,825 \\
\hline Sweden & 0 & 473 & 49 & 331 & 468 & 0 & 283 & 258 & 1,862 \\
\hline Switzerland & 285 & 183 & 106 & 77 & 420 & 0 & 232 & 259 & 1,562 \\
\hline UK & 520 & 110 & 0 & 654 & 230 & 0 & 247 & 142 & 1,903 \\
\hline & & & & & & & & & \\
\hline Total & 2,293 & 1,329 & 858 & 2,216 & 2,948 & 1,974 & 2,159 & 2,126 & 15,90 \\
& & & & & & & & & 3 \\
\hline
\end{tabular}


Table I.C Average populist attitudes per party family, per country
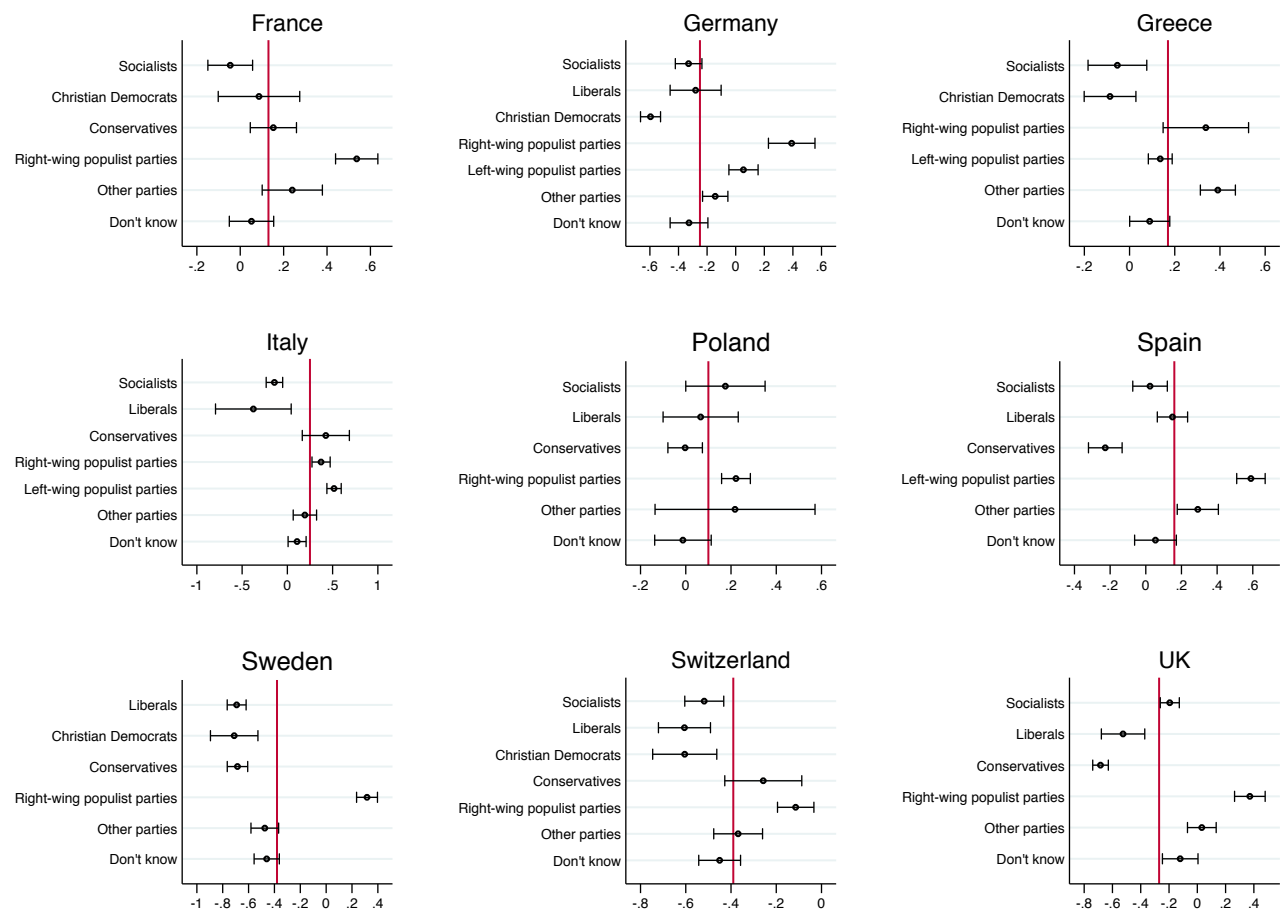

Note: Average values of populist attitudes are portrayed on the X-axes. The vertical red line on each graph represents the country average of populist attitudes. 


\section{Appendix II: Question wordings}

The economic issue positions index is comprised of the following five statements:

1. Incomes should be made more equal | We need larger income differences as incentives.

2. People should take more responsibility to provide for themselves | The government should take more responsibility to ensure that everyone is provided for. (reverse coded)

3. People who are unemployed should have to take any job available or lose their unemployment benefits | People who are unemployed should have the right to refuse a job they do not want. (reverse coded)

4. Competition is good. It stimulates people to work hard and develop new ideas | Competition is harmful. It brings out the worst in people. (reverse coded)

5. Government should decrease taxes a lot and spend much less on social benefits and services | Government should increase taxes a lot and spend much more on social benefits and services. (reverse coded)

The cultural issue positions index is comprised of the following five statements:

1. A woman has to have children in order to be fulfilled |A woman can be fulfilled through her professional career. (reverse coded)

2. A woman who does not want to have a child should be allowed to have a free and safe abortion | Abortion should not be allowed in any case.

3. Children should be taught to obey authority | Children should be encouraged to have an independent judgment. (reverse coded)

4. People who break the law should get tougher sentence | Tougher sentences do not contribute to reduce criminality. (reverse coded)

5. Homosexual couples should be able to adopt children| Homosexual couples should not be allowed to adopt children under any circumstances.

The subjective deprivation variable is a combination of the following five items:

- On a scale from 0 to 10 where 0 means 'Much worse' and 10 means 'Much better', would you say that your own current standard of living is better or worse compared to your parents when they were your age?

- On a scale from 0 to 10 where 0 means 'Much worse' and 10 means 'Much better', would you say that the economic situation of your household now is better or worse to how it was 5 years ago?

- On a scale from 0 to 10 where 0 means 'Much worse' and 10 means 'Much better', would you say that the economic situation of your household now is better or worse than it was 12 months ago? [

- On a scale from 0 to 10 where 0 means 'Much worse' and 10 means 'Much better', would you say that over the past year the state of the economy in COUNTRY has become...?

- The living conditions among European countries differ quite a lot today, and we would like to get your personal evaluation. Please use the scale below, where 0 means 'Very bad living conditions' and 10 means 'Very good living conditions'. $<\mathrm{br} />$ Where on the scale do you place your country?

The political trust variable is a combination of the trust in 1) national parliament, 2) politicians, 3) political parties, 4) the European Union, 5) trade unions, 6) the judicial system, 7) the police / the army, 8) the media, 9) national government, and 10) banks. All answer categories range from 0 (do not trust this institution at all) to 10 (completely trust this institution). 
The internal political efficacy variable combines the following three items:

- I consider myself well-qualified to participate in politics [1 $=$ strongly disagree ; 5 agree strongly]

- I feel that I have a pretty good understanding of the important political issues facing the [COUNTRY] [1 = strongly disagree ; 5 agree strongly]

O I think that I am at least as well-informed about politics and government as most people [1 = strongly disagree ; 5 agree strongly]

The external political efficacy variable combines the following three items:

- Public officials don't care much what people like me think [1 = strongly disagree ; 5 agree strongly]

- People like me don't have any say about what government does $[1=$ strongly disagree ; 5 agree strongly]

- Sometimes politics and government seem so complicated that a person like me can't really understand what's going on [ $1=$ strongly disagree ; 5 agree strongly]

The economic prejudice variable draws from the following question: Would you say it is generally bad or good for the COUNTRY's economy that people come to live here from other countries? Please state your answer on this scale where 0 means 'Bad' and 10 means 'Good'.

The cultural prejudice variable draws from the following question: Would you say that the COUNTRY's cultural life is generally undermined or enriched by people coming to live here from other countries? Please state your answer on this scale where 0 means 'Undermined' and 10 means 'Enriched'. 
Appendix III: Descriptive statistics

Table III.A: Absolute number of populist and non-populist supporters, per country

\begin{tabular}{|l|l|l|l|l|l|}
\hline & $\begin{array}{l}\text { not } \\
\text { populist vote }\end{array}$ & $\begin{array}{l}\text { not } \\
\text { populist vote } \\
\mathbf{( \% )}\end{array}$ & $\begin{array}{l}\text { populist } \\
\text { vote }\end{array}$ & $\begin{array}{l}\text { populist } \\
\text { vote (\%) }\end{array}$ & Total \\
\hline France & 1,332 & 77,26 & 392 & 22,74 & 1,724 \\
\hline Germany & 1,584 & 80,78 & 377 & 19,22 & 1,961 \\
\hline Greece & 878 & 50,58 & 858 & 49,42 & 1,736 \\
\hline Italy & 863 & 49,51 & 880 & 50,49 & 1,743 \\
\hline Poland & 955 & 52,21 & 874 & 47,79 & 1,829 \\
\hline Spain & 1,376 & 76,49 & 423 & 23,51 & 1,799 \\
\hline Sweden & 1,292 & 73,41 & 468 & 26,59 & 1,760 \\
\hline Switzerland & 1,367 & 76,50 & 420 & 23,50 & 1,787 \\
\hline UK & 1,650 & 87,77 & 230 & 12,23 & 1,880 \\
\hline & & & & & 30,54 \\
\hline Total & 11,265 & 69,46 & 4,954 & 16,219 \\
\hline
\end{tabular}


Table III.B: Descriptive statistics of populist attitudes, per country

\begin{tabular}{|l|l|l|l|l|l|l|l|l|l|}
\hline $\begin{array}{l}\text { count } \\
\text { ry }\end{array}$ & $\mathbf{N}$ & mean & $\begin{array}{l}\text { media } \\
\mathbf{n}\end{array}$ & $\begin{array}{l}\text { std. } \\
\text { dev. }\end{array}$ & $\begin{array}{l}\text { skew } \\
\text { ness }\end{array}$ & $\begin{array}{l}\text { kurto } \\
\text { sis }\end{array}$ & alpha & min. & max. \\
\hline France & 2027 & 0.13 & 0.10 & 1.01 & -0.28 & 3.06 & 0.9053 & -3.48 & 1.81 \\
\hline $\begin{array}{l}\text { Germ } \\
\text { any }\end{array}$ & 2108 & -0.25 & -0.31 & 0.88 & 0.20 & 3.19 & 0.8765 & -3.48 & 1.81 \\
\hline $\begin{array}{l}\text { Greec } \\
\text { e }\end{array}$ & 2048 & 0.17 & 0.09 & 0.81 & -0.08 & 3.69 & 0.8245 & -3.48 & 1.81 \\
\hline Italy & 2040 & 0.25 & 0.25 & 0.96 & -0.40 & 3.11 & 0.8808 & -3.48 & 1.81 \\
\hline $\begin{array}{l}\text { Polan } \\
\text { d }\end{array}$ & 2024 & 0.10 & 0.09 & 0.94 & -0.54 & 3.90 & 0.8712 & -3.48 & 1.81 \\
\hline Spain & 2035 & 0.16 & 0.18 & 0.90 & -0.34 & 3.45 & 0.8639 & -3.48 & 1.81 \\
\hline $\begin{array}{l}\text { Swede } \\
\mathrm{n}\end{array}$ & 2018 & -0.38 & -0.52 & 0.94 & 0.32 & 3.32 & 0.8884 & -3.48 & 1.81 \\
\hline $\begin{array}{l}\text { Switze } \\
\text { rland }\end{array}$ & 2046 & -0.39 & -0.43 & 0.81 & 0.20 & 3.87 & & -3.48 & 1.81 \\
\hline UK & 2022 & -0.27 & -0.31 & 0.86 & 0.26 & 3.10 & 0.8604 & -3.48 & 1.81 \\
\hline & & & & & & & & & \\
\hline Total & 18368 & -0.05 & -0.08 & 0.94 & -0.06 & 3.08 & 0.8753 & -3.48 & 1.81 \\
\hline
\end{tabular}


Table III.C: Descriptive statistics

\begin{tabular}{|c|c|c|c|c|c|}
\hline var name & $\mathbf{n}$ & mean & std dev & $\min$ & $\max$ \\
\hline gender $(0=$ male $)$ & 18368 & 0.53 & 0.50 & 0 & 1 \\
\hline age & 18368 & 44.46 & 14.89 & 18 & 95 \\
\hline age squared & 18368 & 2198.23 & 1370.51 & 324 & 9025 \\
\hline $\begin{array}{l}\text { education group }(1=\text { less than } \\
\text { secondary; } 2=\text { secondary; } 3= \\
\text { university) }\end{array}$ & 18368 & 2.08 & 0.74 & 1 & 3 \\
\hline income (brackets) & 15630 & 4.81 & 2.74 & 1 & 10 \\
\hline $\begin{array}{l}\text { social class }(0=\text { lower class; } 6= \\
\text { upper class })\end{array}$ & 16864 & 3.10 & 1.10 & 1 & 6 \\
\hline household size & 18079 & 2.61 & 1.35 & 0 & 15 \\
\hline $\begin{array}{l}\text { marital status ( } 1 \text { never married, } \\
\text { civil partnership, legally separated, } \\
\text { legally divorced, widowed, } 6= \\
\text { legally married) }\end{array}$ & 18368 & 3.65 & 2.22 & 1 & 6 \\
\hline $\begin{array}{l}\text { subjective domicile }(1=\text { big city; } 5 \\
=\text { farm })\end{array}$ & 18368 & 2.50 & 1.17 & 1 & 5 \\
\hline $\begin{array}{l}\text { economic prejudice }(0=\text { low } ; 10= \\
\text { high })\end{array}$ & 17364 & 5.15 & 2.85 & 0 & 10 \\
\hline $\begin{array}{l}\text { cultural prejudice }(0=\text { low } ; 10= \\
\text { high })\end{array}$ & 17293 & 4.88 & 2.94 & 0 & 10 \\
\hline subjective deprivation* & 16471 & 5.98 & 2.31 & 0 & 100 \\
\hline social trust $(0=$ low $; 10=$ high $)$ & 17727 & 4.25 & 2.64 & 0 & 10 \\
\hline $\begin{array}{l}\text { political trust }(0=\text { low } ; 100= \\
\text { high })^{* *}\end{array}$ & 16588 & 5.42 & 2.52 & 0 & 100 \\
\hline $\begin{array}{l}\text { political interest }(1=\text { low } ; 5= \\
\text { high })\end{array}$ & 18368 & 2.81 & 0.90 & 1 & 5 \\
\hline $\begin{array}{l}\text { internal political efficiacy }(0=\text { low } \\
100=\text { high })^{* * *}\end{array}$ & 18368 & 3.39 & 0.91 & 0 & 100 \\
\hline $\begin{array}{l}\text { external political efficiacy }(0=\text { low } \\
; 100=\text { high })^{* * *}\end{array}$ & 18368 & 3.23 & 0.84 & 0 & 100 \\
\hline
\end{tabular}




\begin{tabular}{|l|l|l|l|l|l|}
\hline partisan affiliation $(0=$ no) & 17044 & 0.81 & 0.39 & 0 & 1 \\
\hline $\begin{array}{l}\text { satisfaction w/ democracy }(1=\text { low } \\
; 11=\text { high) }\end{array}$ & 17608 & 5.72 & 2.62 & 1 & 11 \\
\hline $\begin{array}{l}\text { dissatisfaction w/ economic } \\
\text { policies }(0=\text { low ; } 10=\text { high })\end{array}$ & 17609 & 6.14 & 2.84 & 0 & 10 \\
\hline $\begin{array}{l}\text { dissatisfaction w/ immigration } \\
\text { policies }(0=\text { low } ; 10=\text { high) }\end{array}$ & 17551 & 7.13 & 2.57 & 0 & 10 \\
\hline culttural left-right & 15530 & 5.06 & 2.35 & 0 & 11.73 \\
\hline economic left-right & 16411 & 6.41 & 2.31 & 0 & 11.34 \\
\hline populist attitudes & 18368 & -0.05 & 0.94 & -3.48 & 1.81 \\
\hline
\end{tabular}

Note: ${ }^{*}$ This is the result of a CFA of five separate pocket-book items that indicate subjective relative deprivation (alpha $=0.84$ and $\mathrm{EV}=2.54$ ); ** This is the result of a CFA of 10 separate survey items that indicate political trust (alpha $=0.91$ and EV $=$ 5.17); *** Both internal and external efficacy is the result of a CFA of three separate survey items that indicate efficacy. 
Appendix IV: Full model for the populist vote choice models

Table IV.1: Models with socio-demographics only

\begin{tabular}{|l|l|l|}
\hline & model 1a & model 1b \\
\hline (coefficients) & $\begin{array}{l}\text { left-wing } \\
\text { populism }\end{array}$ & $\begin{array}{l}\text { right-wing } \\
\text { populism }\end{array}$ \\
\hline gender & -0.013 & $-0.346^{* * *}$ \\
\hline & $(0.061)$ & $(0.049)$ \\
\hline age & -0.003 & 0.012 \\
\hline & $(0.014)$ & $(0.010)$ \\
\hline age squared & -0.000 & -0.000 \\
\hline & $(0.000)$ & $(0.000)$ \\
\hline education group & $0.081 *$ & $-0.265^{* * *}$ \\
\hline & $(0.043)$ & $(0.035)$ \\
\hline income & $-0.038^{* * *}$ & -0.017 \\
\hline & $(0.014)$ & $(0.011)$ \\
\hline social class & $-0.209 * * *$ & -0.028 \\
\hline & $(0.035)$ & $(0.025)$ \\
\hline household size & -0.008 & $0.036^{*}$ \\
\hline & $(0.025)$ & $(0.020)$ \\
\hline marital status & 0.005 & 0.019 \\
\hline & $(0.016)$ & $(0.013)$ \\
\hline subjective domicile & $-0.082^{* * *}$ & $0.094 * * *$ \\
\hline & $(0.028)$ & $(0.022)$ \\
\hline Orob $>$ chi2 & -3331.757 & -5279.823 \\
\hline & 6,031 & 11,566 \\
\hline & 4 & 8 \\
\hline & 99.38 & 162.73 \\
\hline & & 0.000 \\
\hline & & \\
\hline & & \\
\hline & & \\
\hline
\end{tabular}

Note: Standard errors in parentheses; ${ }^{* * *} \mathrm{p}<0.01,{ }^{* *} \mathrm{p}<0.05,{ }^{*} \mathrm{p}<0.1$ 
Table IV.2: Models with political and attitudinal variables

\begin{tabular}{|c|c|c|c|c|}
\hline & model $2 \mathrm{a}$ & model 2b & model 3a & model 3b \\
\hline (coefficients) & $\begin{array}{l}\text { left-wing } \\
\text { populism }\end{array}$ & $\begin{array}{l}\text { right-wing } \\
\text { populism }\end{array}$ & $\begin{array}{l}\text { left-wing } \\
\text { populism }\end{array}$ & $\begin{array}{l}\text { right-wing } \\
\text { populism }\end{array}$ \\
\hline \multirow[t]{2}{*}{ social class } & $-0.133^{* * *}$ & & $-0.136^{* * *}$ & \\
\hline & $(0.040)$ & & $(0.040)$ & \\
\hline \multirow[t]{2}{*}{ income } & $-0.046^{* * *}$ & & $-0.045^{* * *}$ & \\
\hline & $(0.016)$ & & $(0.016)$ & \\
\hline \multirow[t]{2}{*}{ gender } & & $-0.103^{*}$ & & $-0.104^{*}$ \\
\hline & & $(0.062)$ & & $(0.062)$ \\
\hline \multirow[t]{2}{*}{ education groups } & & $-0.187 * * *$ & & $-0.186^{* * *}$ \\
\hline & & $(0.042)$ & & $(0.042)$ \\
\hline \multirow[t]{2}{*}{ economic prejudice } & 0.009 & $0.047 * * *$ & 0.008 & $0.047 * * *$ \\
\hline & $(0.019)$ & $(0.016)$ & $(0.018)$ & $(0.016)$ \\
\hline \multirow[t]{2}{*}{ cultural prejudice } & $-0.050 * * *$ & $0.178^{* * *}$ & $-0.049 * * *$ & $0.177^{* * *}$ \\
\hline & $(0.018)$ & $(0.016)$ & $(0.018)$ & $(0.016)$ \\
\hline \multirow[t]{2}{*}{ subjective deprivation } & -0.015 & $-0.065^{* * *}$ & -0.013 & $-0.064 * * *$ \\
\hline & $(0.022)$ & $(0.017)$ & $(0.022)$ & $(0.017)$ \\
\hline \multirow[t]{2}{*}{ social trust } & 0.010 & 0.010 & 0.010 & 0.010 \\
\hline & $(0.017)$ & $(0.014)$ & $(0.017)$ & $(0.014)$ \\
\hline \multirow[t]{2}{*}{ political trust } & $-0.096 * * *$ & -0.015 & $-0.097 * * *$ & -0.015 \\
\hline & $(0.019)$ & $(0.016)$ & $(0.019)$ & $(0.016)$ \\
\hline \multirow[t]{2}{*}{ political interest } & $0.166^{* * *}$ & $0.107^{* *}$ & $0.162^{* * *}$ & $0.106^{* *}$ \\
\hline & $(0.050)$ & $(0.045)$ & $(0.050)$ & $(0.045)$ \\
\hline \multirow[t]{2}{*}{ internal political efficacy } & $-0.108^{* *}$ & -0.017 & $-0.102^{* *}$ & -0.016 \\
\hline & $(0.051)$ & $(0.043)$ & $(0.051)$ & $(0.043)$ \\
\hline \multirow[t]{2}{*}{ external political efficacy } & $-0.150 * * *$ & 0.052 & $-0.155^{* * *}$ & 0.050 \\
\hline & $(0.048)$ & $(0.040)$ & $(0.048)$ & $(0.040)$ \\
\hline \multirow[t]{2}{*}{ partisan affiliation } & $0.861 * * *$ & $0.905^{* * *}$ & $0.859 * * *$ & $0.904 * * *$ \\
\hline & $(0.115)$ & $(0.111)$ & $(0.114)$ & $(0.111)$ \\
\hline \multirow[t]{2}{*}{ satisfaction w/ democracy } & $-0.037 * *$ & $-0.110^{* * *}$ & $-0.036^{* *}$ & $-0.109 * * *$ \\
\hline & $(0.017)$ & $(0.016)$ & $(0.017)$ & $(0.016)$ \\
\hline \multirow[t]{2}{*}{ dissatisfaction $\mathrm{w} /$ economic policies } & -0.010 & $-0.045^{* * *}$ & -0.013 & $-0.045^{* * *}$ \\
\hline & $(0.020)$ & $(0.016)$ & $(0.020)$ & $(0.016)$ \\
\hline \multirow[t]{2}{*}{$\begin{array}{l}\text { dissatisfaction w/ immigration } \\
\text { policies }\end{array}$} & $-0.041 * *$ & $0.160^{* * *}$ & $-0.039 * *$ & $0.159 * * *$ \\
\hline & $(0.020)$ & $(0.017)$ & $(0.020)$ & $(0.017)$ \\
\hline \multirow[t]{2}{*}{ cultural left-right } & $-0.123 * * *$ & $0.147 * * *$ & $-0.123 * * *$ & $0.153^{* * *}$ \\
\hline & $(0.018)$ & $(0.014)$ & $(0.018)$ & $(0.015)$ \\
\hline \multirow[t]{2}{*}{ economic left-right } & $-0.150 * * *$ & 0.009 & $-0.169 * * *$ & 0.010 \\
\hline & $(0.017)$ & $(0.014)$ & $(0.018)$ & $(0.014)$ \\
\hline \multirow[t]{2}{*}{ populist attitudes } & $0.302^{* * *}$ & $0.181 * * *$ & 0.023 & $0.314 * * *$ \\
\hline & $(0.049)$ & $(0.041)$ & $(0.109)$ & $(0.094)$ \\
\hline \multirow[t]{2}{*}{$\begin{array}{l}\text { economic left-right \# populist } \\
\text { attitudes }\end{array}$} & & & $0.049^{* * *}$ & \\
\hline & & & $(0.017)$ & \\
\hline
\end{tabular}




\begin{tabular}{|l|l|l|l|l|}
\hline $\begin{array}{l}\text { cultural left-right \# populist } \\
\text { attitudes }\end{array}$ & & & & -0.022 \\
\hline & & & & $(0.014)$ \\
\hline & & & & \\
\hline Observations & 4,860 & 9,767 & 4,860 & 9,767 \\
\hline Number of countries & 4 & 8 & 4 & 8 \\
\hline LR chi2(17) & 488.03 & 1278.01 & 496.16 & 1272.60 \\
\hline Prob > chi2 & 0.000 & 0.000 & 0.000 & 0.000 \\
\hline Log likelihood & -2527.046 & -3678.411 & -2522.995 & -3677.183 \\
\hline
\end{tabular}

Note: Standard errors in parentheses; ${ }^{* * *} \mathrm{p}<0.01,{ }^{* *} \mathrm{p}<0.05,{ }^{*} \mathrm{p}<0.1$ 
Appendix V: Marginal plots for the interaction terms, with policy preferences as the moderator

Figure V.1 The average marginal effect of populist attitudes on the likelihood to support a left-wing populist party, according to economic policy preferences.

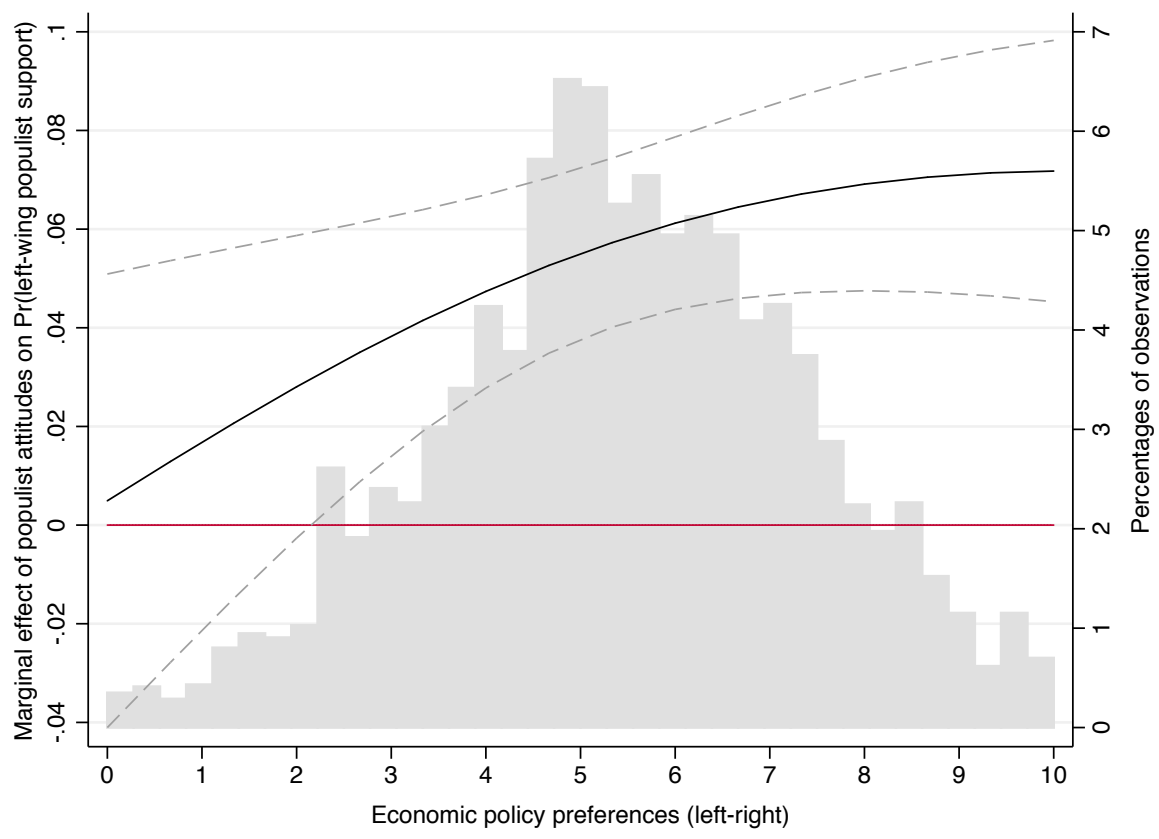

Figure V.1 The average marginal effect of populist attitudes on the likelihood to support a right-wing populist party, according to cultural policy preferences.

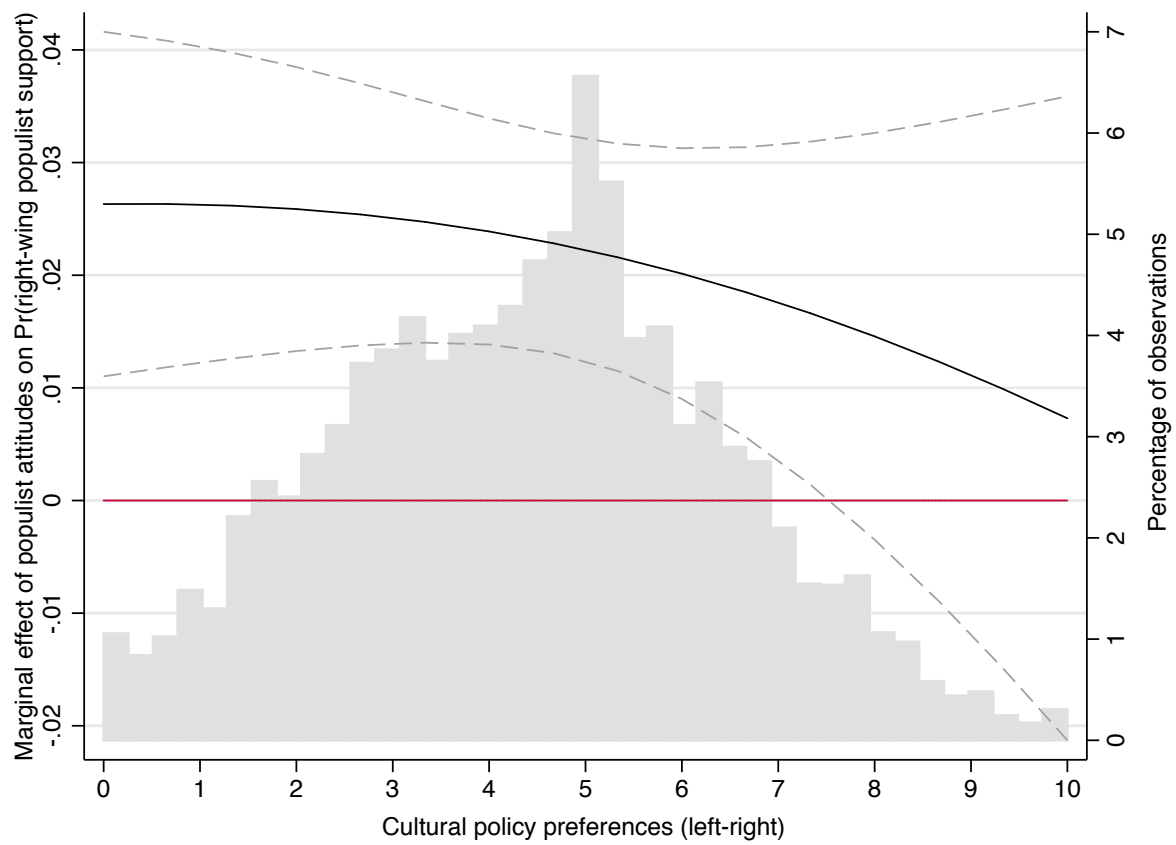

